\title{
Link between Diabetes and Alzheimer's Disease Due to the Shared Amyloid Aggregation and Deposition Involving Both Neurodegenerative Changes and Neurovascular Damages
}

\author{
Gabriela Dumitrita Stanciu ${ }^{1,+} \oplus$, Veronica Bild ${ }^{1,2, *}$, Daniela Carmen Ababei ${ }^{2,+}$, \\ Razvan Nicolae Rusu ${ }^{2}$, Alina Cobzaru ${ }^{2}$, Luminita Paduraru ${ }^{3, *}$ and Delia Bulea ${ }^{2}$ \\ 1 Center for Advanced Research and Development in Experimental Medicine (CEMEX), Grigore T. Popa" \\ University of Medicine and Pharmacy, 16 Universitatii Street, 700115 Iasi, Romania; \\ gabriela-dumitrita.s@umfiasi.ro \\ 2 Pharmacodynamics and Clinical Pharmacy Department, Grigore T. Popa" University of Medicine and \\ Pharmacy, 16 Universitatii Street, 700115 Iasi, Romania; dana.ababei@gmail.com (D.C.A.); \\ razvan.nicolae.rusu@gmail.com (R.N.R.); alimoraru23@yahoo.com (A.C.); dbulea@yahoo.com (D.B.) \\ 3 Department Mother \& Child Care, Division Neonatology, Grigore T. Popa" University of Medicine and \\ Pharmacy, 16 Universitatii Street, 700115 Iasi, Romania \\ * Correspondence: veronica.bild@gmail.com (V.B.); luminita.paduraru@gmail.com (L.P.) \\ + These authors contributed equally to this work.
}

Received: 6 May 2020; Accepted: 29 May 2020; Published: 3 June 2020

\begin{abstract}
Diabetes and Alzheimer's disease are two highly prevalent diseases among the aging population and have become major public health concerns in the 21st century, with a significant risk to each other. Both of these diseases are increasingly recognized to be multifactorial conditions. The terms "diabetes type 3" or "brain diabetes" have been proposed in recent years to provide a complete view of the potential common pathogenic mechanisms between these diseases. While insulin resistance or deficiency remains the salient hallmarks of diabetes, cognitive decline and non-cognitive abnormalities such as impairments in visuospatial function, attention, cognitive flexibility, and psychomotor speed are also present. Furthermore, amyloid aggregation and deposition may also be drivers for diabetes pathology. Here, we offer a brief appraisal of social impact and economic burden of these chronic diseases and provide insight into amyloidogenesis through considering recent advances of amyloid- $\beta$ aggregates on diabetes pathology and islet amyloid polypeptide on Alzheimer's disease. Exploring the detailed knowledge of molecular interaction between these two amyloidogenic proteins opens new opportunities for therapies and biomarker development.
\end{abstract}

Keywords: diabetes; Alzheimer's disease; amyloidogenic diseases; islet amyloid polypeptide; amyloid- $\beta$ peptide; neurodegenerative changes; neurovascular damages; in vivo models

\section{Socio-Economic Burden of Diabetes and Alzheimer's Disease}

Diabetes, both type 1 and 2, and Alzheimer's disease (AD) are vastly prevalent conditions among the elderly population, with a multifactorial nature involving various biological mechanisms that continue to be important, as well as growing health challenges worldwide [1]. Due to its continuous rise of prevalence in developed and developing countries over recent years, diabetes is considered a global key health priority. Estimates show that in most countries the burden put out by the disease is increasing, this being evidence of an increase of risk in the population [2]. The number of people living with diabetes tripled between 1990 and 2010, whilst the number of new cases annually doubled [3]. 
There are approximately 463 million patients worldwide $(9.3 \%)$ affected by the disease rising to 578 million (10.2\%) by 2030 and 700 million by 2045 (10.9\%) [4]. The absolute global cost of diabetic patients in 2018 has been estimated at $\$ 1.6$ trillion, which corresponds to a gross domestic product of $1.8 \%$, and this figure will increase to $\$ 2.5$ trillion annually by 2030 (Figure 1) [5].

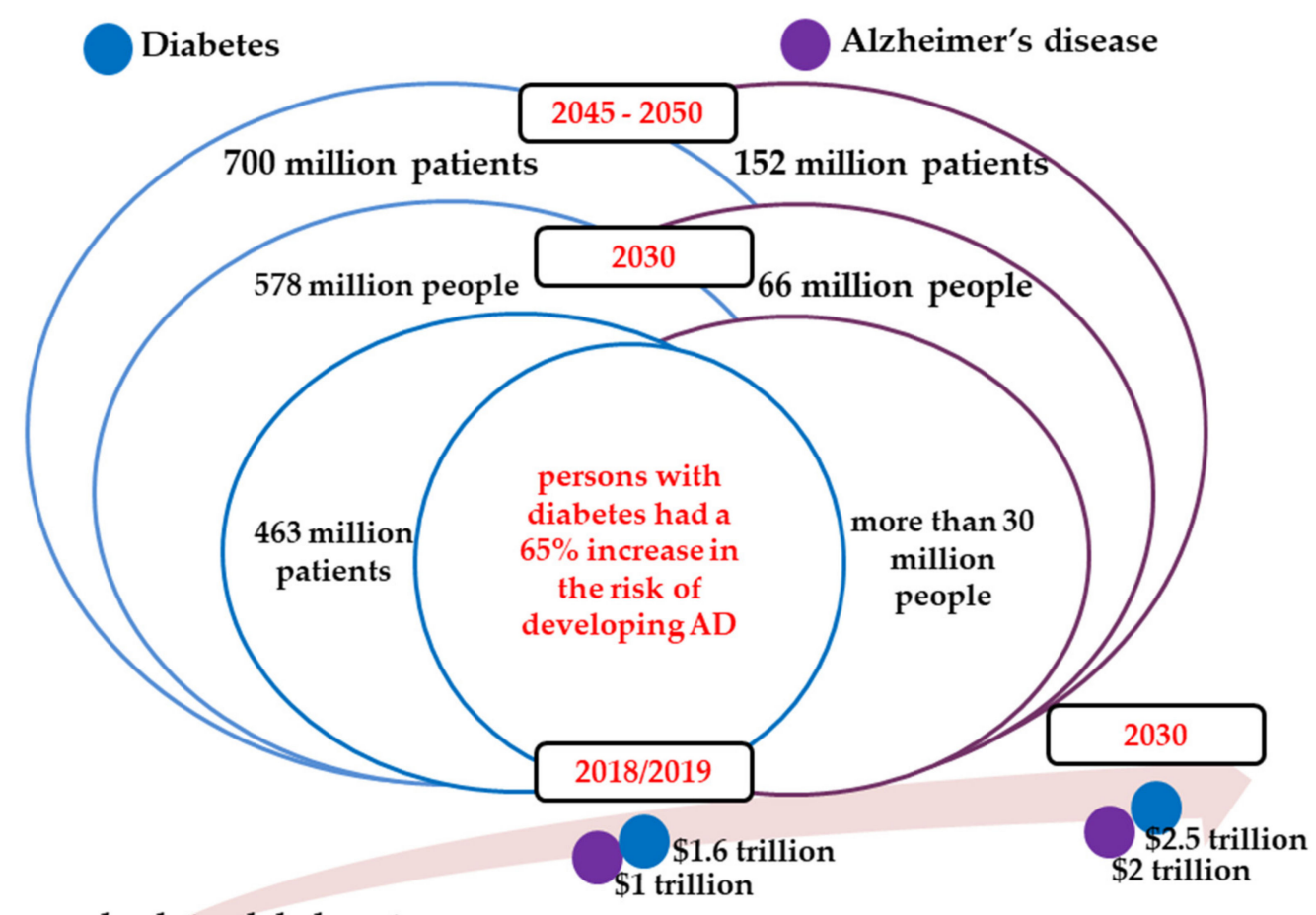

absolute global costs

Figure 1. Global diabetes and Alzheimer's disease (AD) prevalence estimates and economic burden for 2018/2019 and projections to 2030 and 2050.

$\mathrm{AD}$ is an irreversible, progressive form of dementia culminating in gradual memory loss, various cognitive impairments, and intellectual incapacities that interfere with quality of life [6]. In an attempt to update the guidelines toward a biological definition of Alzheimer's disease, the National Institute on Aging and Alzheimer's Association Research Framework has generated distinct diagnostic recommendations for the preclinical, mild cognitive impairment, and dementia stages of AD. It has become clearer that $\mathrm{AD}$ is both a pathophysiological condition and a clinical entity at the same time; specifically, Alzheimer's disease begins decades before the onset of the earliest clinical manifestations, and Alzheimer's dementia is the actual last condition in which AD culminates [7]. Around the world, nearly 50 million people were afflicted with dementia in 2018, and AD accounted for $60 \%$ to $80 \%$ of these cases. In the coming three decades, this number is projected to more than triple, at 152 million. The total estimated overall cost for the care of AD patients in 2018 was estimated at $\$ 1$ trillion, which corresponds to a gross domestic product of $1.2 \%$, and this figure will increase to $\$ 2$ trillion annually by 2030 - costs that can weaken social and economic development and could overwhelm health and social services (Figure 1) [1,6]. Moreover, these chronic conditions are no longer a problem only for high-income countries. More than two-thirds of all diabetes and AD patients live in the United States of America, India, Brazil, and China, and this percentage will increase by $2050[4,8]$.

The high individual, familial, social, and financial burden of diabetes and AD requires bold and critical plans. As a result, most states and many international organizations have elaborated strategies and analytical reports to solve the problem [4], and research based on mathematical and animal models or on qualified estimates are trying to predict the development of diabetes in relation to AD. Table 1 shows the current pharmacotherapeutic approaches in diabetes and AD. Existing results do not support 
the repurposing of diabetes therapies for dementia risk decrease or management. Studies in the field of diabetes and AD are active, and additional data are required before final conclusions can be drawn.

Table 1. Current therapies in diabetes and Alzheimer's disease.

Insulin
Biguanides: Metformin
Sulphonylureas: Glibenclamide, Glibornuride, Glipizide, Gliquidone, Glisoxepide,
Glyclopyramide, Glimepiride
Diabetes
Alpha-glucosidase inhibitors: Acarbose, Miglitol, Voglibose
Incretins
Dipeptidyl peptidase-4 inhibitors: Sitagliptin, Saxagliptin, Linagliptin, Alogliptin
Glucagon-like peptide-1 receptor agonists: Exenatide, Liraglutide, Albiglutide, Dulaglutide
Thiazolidinediones: Pioglitazone, Rosiglitazone
SGLT2 Inhibitors: Empagliflozin, Canagliflozin, Dapagliflozin, Ipragliflozin
Meglitinides: Repaglinide, Nateglinide
Amylin analog: Pramlintide
Alzheimer's Disease
Cholinesterase inhibitors: Tacrine, Donepezil, Rivastigmine, Galantamine
N-methyl-D-aspartate receptor: Memantine

In the present paper, we sought to offer a brief overview of social impact and economic burden of these chronic diseases and provide insight into amyloidogenesis in light of recent advances of amyloid- $\beta$ aggregates on diabetes pathology and islet amyloid polypeptide on AD. Exploring the detailed knowledge of molecular interaction between these two amyloidogenic proteins opens new opportunities for therapies and biomarker development that can prevent or reduce the occurrence of diabetes, as well as AD.

\section{Amyloid Formation as a Common Pathological Feature in both Diabetes and Alzheimer's Disease}

\subsection{Relations between Diabetes and Alzheimer's Disease}

Since the beginning of the 21st century, multiple studies have highlighted the potential links between $\mathrm{AD}$ and abnormalities of insulin signaling related with diabetes. The link seems to be so robust that $\mathrm{AD}$ is frequently considered a neuroendocrine disorder referred to as "diabetes type 3 " or "brain diabetes" [9]. It was found that diabetic patients had a $65 \%$ increase in the risk of developing AD and display lower basal cognitive skills including learning, memory, and perceptual speed [10]. Somewhat surprisingly, AD and diabetes share several risk factors, such as, higher cholesterol, degeneration, beta-amyloid deposition [11], oxidative stress, inflammation cardiovascular disorders, dysmetabolism syndrome [12], glycogen synthesis kinase 3, $\tau$ protein phosphorylation [13], apolipoprotein E4 [14], and apoptosis. In addition, reports have revealed that insulin contributes substantially to neurological function by stimulating the expression of the enzyme that controls the acetylcholine synthesis. Consequently, suboptimal insulin values as well as low insulin receptor sensitivity could eventually contribute to a reduction in acetylcholine, which leads to a likely biochemical link between diabetes and AD [8,11,14]. Such associations can reveal a direct effect of uncontrolled hyperglycaemia on neurodegenerative changes in the brain. This can also be due to diabetes-related comorbidities (e.g., hypertension, dyslipidaemia), or can be an effect of hyperinsulinemia or impaired insulin response [15-17]. Hyperinsulinemia, which comes with diabetes type 2, is a factor that links $\mathrm{AD}$ and diabetes, being related to amyloid-beta peptide $(\mathrm{A} \beta)$ accumulation in the brain. By competing for the insulin-degrading enzyme, it disrupts brain $A \beta$ clearance. In the pathogenesis of diabetes, receptors for advanced glycation end-products are also involved. These receptors can be present in cells associated with senile plaques, with neurofibrillary tangles being a cell surface receptor for $\mathrm{A} \beta$. Another predisposing diabetes factor is the excess of adipose tissue, through production of adipocytes critical to metabolism and cytokines involved in the inflammatory process. Adiponectin, leptin, resistin, tumor necrosis factor alpha (TNF- $\alpha$ ) and interleukin 6 (IL-6) are produced, being tied 
to insulin resistance and hyperinsulinemia, thus directly or indirectly affecting AD risk [18]. Using brain imaging, subjects with diabetes have hippocampal and amygdala atrophy when compared to nondiabetic subjects. The hippocampus and amygdala are responsible for functions such as behavior and memory and are also atrophied in AD. Brain microvascular lesions and extensive amyloid plaque burden coexist in brains of patients with diabetes and dementia, as shown in post-mortem studies, with these characteristics being present in AD as well [19]. Reduced morbidities and premature deaths will lead to a longer life for patients with diabetes, but this will increase costs because of the necessary management of the multiple chronic conditions the disease is associated with. Population with undiagnosed and untreated diabetes mellitus type 2 are at a superior risk of complications compared with those who are receiving treatment. In many cases, the onset of diabetes mellitus often happens years before the concrete diagnosis, being considered that approximately 174.8 million cases were undiagnosed [20].

\subsection{Amyloid Formation and Deposition Involving both Neurodegenerative Changes and Neurovascular Damage}

The pathological process of amyloidogenesis, in which proteins or peptides self-assemble naturally into higher order structures, called oligomers, protofibrils, and mature amyloid fibrils, occurs in several diseases, including $\mathrm{AD}$ and diabetes. However, data highlighting whether these various forms of amyloid proteins interact or how the formation of these amyloid structures begins are very scarce [21,22]. Amyloids gather into aggregates forming $\mathrm{A} \beta$ oligomers and fibrils in $\mathrm{AD}$ and islet amyloid polypeptide (IAPP) or amylin in diabetes. IAPP is one of the most important $\beta$-cell secretory products of the pancreatic islets of Langerhans. With putative function, IAPP is a regulatory peptide both locally in the islets, where it inhibits insulin and glucagon secretion, and at distant targets. It has binding sites in the brain, possibly contributing to the regulation of satiety and inhibition of gastric emptying, and has also been described as having effects on several other organs over time. IAPP has been identified due to its ability to aggregate in the amyloid deposits of pancreatic islets, which are seen primarily in association with type 2 diabetes in humans and diabetes in several other mammalian species, especially monkeys and cats [23]. At present, it is increasingly accepted that there are close correlations between these two diseases by overlapping their pathology, sharing common complications including impaired carbohydrate metabolism, insulin resistance, oxidative stress, inflammatory response, mitochondrial dysfunction, and amyloidosis (Figure 2) [24].

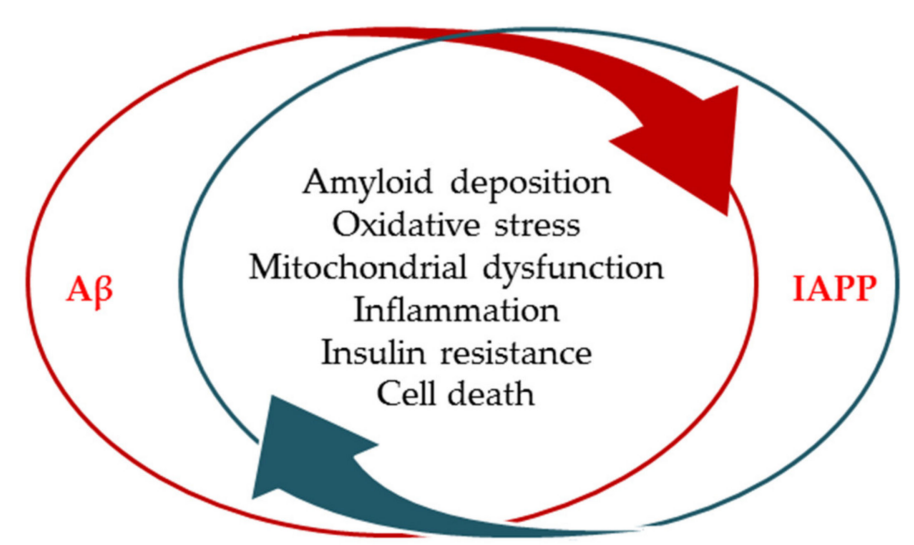

Figure 2. Schematic representation of the correlations between islet amyloid polypeptide of diabetes and amyloid- $\beta$ peptide from Alzheimer's disease; conditions characterized by cell loss and abnormal of $\mathrm{A} \beta$, tau, and amylin deposition. These aggregates could stimulate amyloid formation and deposition by cross-seeding in pancreatic cells and neurons. The presence of tau and amylin aggregates supports the aggregation of beta-amyloid deposits, which leads to oxidative stress, mitochondrial abnormalities, inflammation, insulin resistance, and ultimately death of cells. A $\beta$, amyloid- $\beta$ peptide; IAPP, islet amyloid polypeptide. 
Although several pathological processes appear to be shared in both diabetes and $\mathrm{AD}$, the molecular mechanism underlying these conditions is not completely known [25]. Like $A \beta$ deposition in $A D$, IAPP is also aggregated in people with diabetes to form pancreatic islet amyloid, and its detection in brain tissue has been linked with cognitive decline. Structurally, IAPP and human A $\beta$ contain a total of $25 \%$ identical amino acid sequences that have high binding affinity, many biophysical and physiological properties, and which exert similar cytotoxic mechanisms when aggregated. Additionally, in patients with AD, IAPP deposits that contribute to the pathophysiology of the disease were found in the brain tissue [26].

IAPP is synthesized and secreted by $\beta$-cells of the pancreatic islets of Langerhans, together with insulin. Typically, IAPP is co-secreted with insulin at a molar ratio of 1:100 [27]. In $\beta$-cell secretory granules, IAPP is mainly located in the halo region, whereas insulin is stored in the dense core of $\beta$-cells in microcrystalline groups [28]. In humans, IAPP is secreted by hormone pluripotent endocrine stem cells in all stages of embryonic development. The first IAPP-positive cell appears after only 13 weeks of gestation. The gene encoding IAPP is located on chromosome number 12 [29]. IAPP is synthesized as a pre-pro form of IAPP that contains 89 amino acids. The 22 amino acid signal peptide is cleaved to give the 67 amino acid pro-form (pro-IAPP). Pro-IAPP is processed in the Golgi apparatus and in the insulin secretory granules $[26,30,31]$. The physiological roles of soluble IAPP in the body are not yet fully known. IAPP is a gluco-modulatory hormone that inhibits insulin secretion, delays gastric emptying inhibits appetite, and plays a role in regulating food intake and controlling body weight [31]. The IAPP belongs to the calcitonin family of hormones, presents the functions of "bone remodelling", inhibits osteoclast activity, and enhances osteoblast proliferation [29]. Several studies have explored the mechanisms responsible for the formation of amyloid deposits, which explain the cytotoxic effects of IAPP. Amylin is a peptide with 37 amino acid residues. The sequence in the 20-29 regions determines its ability to form amyloid deposits. Humans, non-human primates, and cats form in vivo deposits of amyloid. It is a phenomenon not found in rats and mice [30], as there is a considerable difference in the amino acid sequence 20-29 in different species. In the cases of mice and rats, there are three proline residues in the 20-29 segments that modify the beta-sheet conformation required for IAPP aggregation. In humans, this segment, called the amyloidogenic region, does not contain proline residues and is essential for IAPP aggregation [26]. Human IAPP levels released from beta cells may be another important factor in the process of amylin aggregation [32,33]. Poor processing of pro-IAPP also plays a central role in the aggregation of IAPP and in the formation of amyloid deposition in vivo [30]. In order to form amyloid deposits, it is necessary to use different biological, chemical, or physical factors [31]. A still controversial issue is whether IAPP aggregation is initiated intracellularly or extracellularly. Identifying the initial site of aggregation is important in discovering drugs capable of crossing beta cell membranes and thus being able to inhibit the formation of initial IAPP aggregates. The formation of small aggregates in the intracellular space can lead to the death of beta cells. Small aggregates can be secreted into the extracellular zone where they can then act as seeds for further propagation of amyloid deposits into the extracellular space [26].

Pathologically, amyloid plaques representing extracellular accumulations of $\mathrm{A} \beta$ peptides and intracellular neurofibrillary agglomerations, composed of tau proteins associated with microtubules, are specific to $\mathrm{AD} \mathrm{[34].} \mathrm{The} \mathrm{development} \mathrm{of} \mathrm{amyloid} \mathrm{plaques} \mathrm{is} \mathrm{an} \mathrm{early} \mathrm{and} \mathrm{invariable} \mathrm{attribute} \mathrm{of} \mathrm{AD}$ and the general opinion is that the accumulation of $A \beta$ peptides is an event that triggers tau pathology, resulting in defective neuronal functioning and cell loss. In AD, autosomal dominant $A \beta$ peptides accumulate due to mutations that cause their overproduction. The cause of elevated brain levels of $A \beta$ peptides in $\mathrm{AD}$ is unclear, but most likely is due to defective clearance compared to overproduction. Aggregation of $A \beta$ peptides is a main aspect in the pathogenesis of $\mathrm{AD}$. While amyloid plaques are made of highly ordered fibrils of $A \beta$ peptides, it appears that soluble oligomers of these peptides, probably in the form of small dimers, are much more pathogenic [22,35,36]. There is plenty of evidence to support the amyloid cascade hypothesis as the main hypothesis explaining the mechanisms leading to Alzheimer's disease. This hypothesis states that $A \beta$, a proteolytic fragment of $\beta$-amyloid precursor 
protein (APP), plays a dominant role in pathogenesis. $\mathrm{A} \beta$ peptides are the major protein component of the neuritic plaques characteristic of $\mathrm{AD}$-they are extracellular lesions composed of a central nucleus of aggregated $A \beta$ peptides surrounded by dystrophic neurites, activated microglia, and reactive astrocytes $[26,37,38]$. It has been shown that aggregate forms of synthetic $A \beta$ peptides can affect neuronal cell cultures in vitro. Recent research suggests that soluble oligomeric prefibrillar forms of $A \beta$ (so-called diffusible $A \beta$ derivatives (ADDLs) or protofibrils), rather than highly aggregated $A \beta$ forms, may be neurotoxic and cause synaptic dysfunction [39]. The alleged sequence of major pathological processes leading to neurodegeneration in $\mathrm{AD}$, consistent with the hypothesis of the amyloid cascade issued by Hardy and Selkoe [40], subsequently updated [41], includes:

- Misplaced mutations of the APP, presenilin-1 (PSEN-1), and or presenilin-2 (PSEN-2) genes that may result in increased production of $A \beta 42$ peptides throughout life in the dominant forms of $\mathrm{AD}$ or,

- by impairing the $A \beta$ peptide purification mechanisms that would favor the gradual increase of the $\mathrm{A} \beta 42$ peptide level in the brain in the case of non-dominant forms of AD.

Both processes lead to the accumulation of the $A \beta 42$ peptide in the limbic system, as well as in the associated cortex that initially produced discrete effects on synaptic efficiency. Subsequently, these accumulations of peptides determine the formation of dispersed plaques that activate microglia and astrocytes and the appearance of the inflammatory effect, which alters neuronal homeostasis. Neuronal dysfunction and loss of neurons lead to imbalances of neurotransmitters that will generate dementia [40,41].

Starting from these subsequent stages that support the hypothesis of amyloid cascade, at present, there are a number of findings that would diminish its importance in AD as well as a series of counterarguments that advocate for the discrepancies [41,42]. In this regard, it was found that a large number of people had abundant $\mathrm{A} \beta$ deposits at the post-mortem autopsy but they were not clearly visible during their life with dementia, and a counter argument would be that these deposits are under the form of diffuse plaques, less neurotoxic up to a certain level $[40,41]$. The failures of several anti-amyloid immunotherapies have led many researchers to reject the hypothesis of amyloid in AD, but the significant efficacy in the phase 3 EMERGE study of an anti-amyloid antibody (aducanumab) is an important validation of amyloid as a therapeutic target [43]. APP is a type I transmembrane protein discovered 30 years ago with a role in the pathogenesis of $\mathrm{AD}$ but that also contributes to regulating important physiological functions such as central and peripheral nervous system development including synaptic plasticity and cognition processes (learning and memory) [44], encoded by the APP gene on chromosome 21 [25]. The APP695 isoform is the predominant form in the central nervous system [26]. To release A $\beta$ from the APP, two cleavages are required, one in the extracellular area (cleavage by $\beta$-secretase) and the other in the transmembrane region (cleavage by $\gamma$-secretase) $[45,46]$. APP is first cleaved within the lumen by $\beta$ or $\alpha$-secretase, resulting in the almost complete "cutting" of the ectodomain and the generation of $\beta$ - or $\alpha$-C-terminal membrane-bound ( $\beta$ - or $\alpha$-CTF) fragments, respectively. These fragments are subsequently cleaved within the transmembrane domain by $\gamma$-secretase with the release of peptides $A \beta(4 \mathrm{kDa})$ and p3 $(3 \mathrm{kDa})$, respectively, into extracellular media. Additionally, cleavage by $\gamma$-secretase generates a cytoplasmic polypeptide called AICD (APP intracellular domain) (Figure 3). 


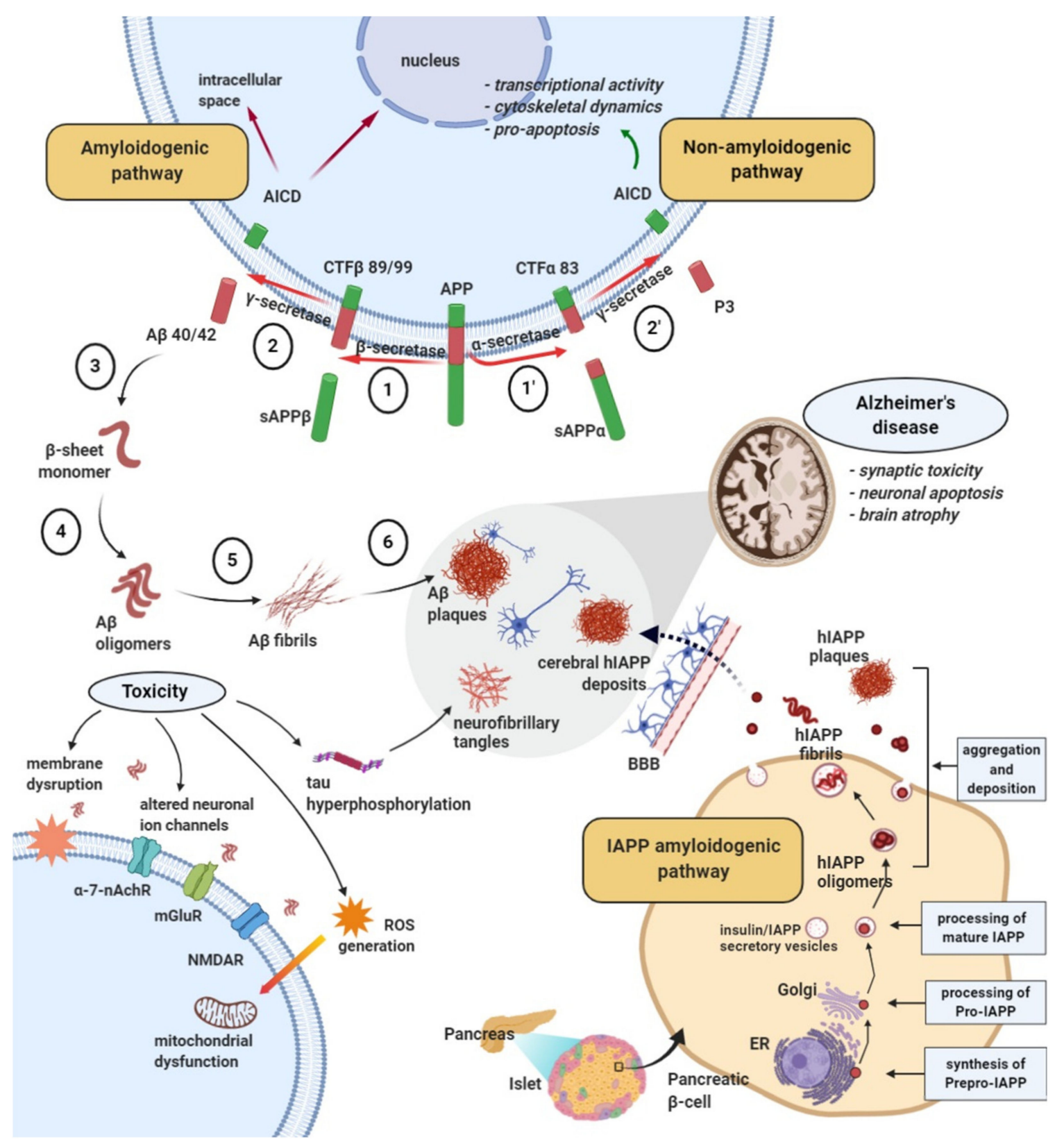

Figure 3. Amyloidogenic pathways of amyloid-beta peptide development in Alzheimer's disease and islet amyloid polypeptide in diabetes. (1) Proteolytic cleavage of the transmembrane glycoprotein $\beta$-amyloid precursor protein (APP) by beta-secretase (amyloidogenic pathway) into the extracellular sAPP $\beta$ and the membrane $\beta$-C-terminal membrane-bound (CTF- $\beta$ ) 89/99 or ( $1^{\prime}$ ) by alpha secretase resulting into extracellular SAPP $\alpha$ and membrane CTF- $\alpha 83$ fragment (non-amyloidogenic pathway). (2) Further cleavage of the CTF- $\beta$ fragments at multiple sites by $\gamma$-secretase, resulting in the formation of extracellular A $\beta$ 40-42 monomers and intracellular APP intracellular domain (AICD) that can translocate to the nucleus ( $\left.2^{\prime}\right)$ CTF- $\alpha$ cleavage by $\gamma$-secretase generating non-toxic extracellular P3 peptide and intracellular AICD. (3) A $\beta$ conformational rearrangement from $\alpha$-helical structure to $\beta$-sheet secondary structure monomers. (4) Assemblage of $\beta$-sheet $A \beta$ monomers into soluble oligomers responsible for neuronal toxicity through mitochondrial dysfunction and membrane receptor binding. (5) Gradual aggregation of $A \beta$ oligomers into insoluble amyloid fibrils and (6) deposits of amyloid senile plaques characteristic of AD. The initially 89 amino acid long islet amyloid polypeptide (IAPP) pre-pro peptides/along with the pro-insulin precursor/are synthesized in the endoplasmic reticulum of the pancreatic islet $\beta$-cells and then processed by enzymatic cleavage at both $C$-terminal and $\mathrm{N}$-terminal 
to 67 amino acid pro-IAPP peptide. The pro-IAPP intermediate is subsequently cleaved by enzymes/prohormone convertase in the Golgi apparatus and in the secretory granules to form the 37 amino acid IAPP molecules. Mature IAPP stored together with insulin in the secretory granules may undergo misfolding processes, leading to potentially toxic intracellular and subsequent extracellular IAPP oligomers. Overexpression of the human IAPP molecules further induces IAPP aggregation into amyloid fibrils and plaques deposited intra- and extracellularly. IAPP oligomers may enter in the brain by crossing the blood-brain barrier, and IAPP deposits may contribute to AD pathology. $\mathrm{A} \beta$, amyloid- $\beta$ peptide; APP, amyloid precursor protein; AICD, cytoplasmic polypeptide; BACE1, beta-secretase 1; BBB, blood-brain barrier.

Non-amyloidogenic processing of APP refers to the sequential processing of APP by membranebound $\alpha$ - and $\gamma$-secretases. A-secretases were the first proteolytic enzymes identified as cleaving APP within the $A \beta$ domain, thus preventing the generation of intact $A \beta$ peptides. Further processing of truncated $A \beta(\mathrm{p} 3)$ and AICD peptides is not fully known. Amyloidogenic processing of APP is accomplished by the sequential action of membrane-bound $\beta$ - and $\gamma$-secretases [46]. Main neuronal $\beta$-secretase is a transmembrane aspartyl protease called BACE1 ( $\beta$-site APP-cleaving enzyme 1$)$. APP cleavage by BACE1 generates N-terminal fragments of A $\beta$ [47].

Subsequent studies have indicated that $\gamma$-secretase, a protein complex, performs enzymatic cleavage at multiple locations within the transmembrane domain of APP, generating A $\beta$ peptides with variable length from 38 to 43 residues. Almost $90 \%$ of the $A \beta$ peptides are generated at residue 40 (A $\beta 40)$, while less than $10 \%$ are generated at residue 42 (A $\beta 42)$. Smaller amounts of shorter peptides (A $\beta 37$ or $A \beta 38$ ) have also been identified. APP mutations identified in familial AD beyond the $C$ terminal of the A $\beta$ domain lead to elevated levels of A $\beta 42[38,39,48]$. Mutations in PSEN-1 and PSEN-2 associated with familial AD influence APP cleavage by $\gamma$-secretase through an unknown mechanism that variably affects the specificity of the cleavage site, generally favoring cleavage at position 42 over position 40 , thus increasing the A $\beta 42 / 40$ ratio. In the normal state, APP is initially cleaved by $\alpha$-secretase with the generation of $\operatorname{sAPP} \alpha$ and a C 83 carboxy-terminal fragment. The presence of $\mathrm{sAPP} \alpha$ is associated with normal synaptic signaling and results in synaptic plasticity, learning and memory, emotional behavior, and neuronal survival. In pathological state, APP is sequentially cleaved by $\beta$-secretase and $\gamma$-secretase with the release of an extracellular fragment called A $\beta 40-42$. This neurotoxic fragment frequently aggregates with $A \beta 40-42$ oligomerization and amyloid plaque formation. A $\beta 40-42$ aggregates cause negative effects such as ion channel blockage and impaired calcium homeostasis, leading to mitochondrial oxidative stress, impaired energy metabolism, abnormal glucose regulation, and, finally, nerve cell death $[21,34,46,49]$, as can be seen in Figure 3 .

\subsection{Evidence from the Shared Pathological Traits}

In recent decades, many clinical studies have shown that patients with diabetes perform less well in activities that involve cognitive processes such as memory, attention, information processing, and executive function. An important role in this regard was found by the cross-sectional clinical study based on the measurement of some cognition indicators affected in diabetes (UDES). In this study, 122 patients with diabetes mellitus aged 56-80 were submitted to brain magnetic resonance imaging (MRI), neurological and neuropsychological examinations, medication evaluation, and measurement of several clinical parameters. The impairment of the cognitive parameters could be caused by the cortical and subcortical atrophy as well as by the brain infarction revealed with the help of the brain MRI [26,50]. Diabetes mellitus is one of the risk factors for the pathogenesis of AD by impairment of insulin signaling and glucose metabolism, both centrally and peripherally [51].

The occurrence of islet amyloid in people with diabetes varies between almost $100 \%$ and $40 \%$ or even less [27]. Maloy et al. [52] evaluated the presence of amyloid deposits in the pancreas in diabetic and non-diabetic patients. It was identified in $59 \%$ of the diabetic cases and $12 \%$ of the non-diabetic cases. Diabetics treated with insulin had the highest prevalence (89\%) and the most severe degree of pancreatic islet amyloidosis. There was an important correlation between the severity of diabetes and 
the prevalence of islet amyloid. The high prevalence of amyloid deposits in diabetic patients treated with insulin and the low presence of amyloid in non-diabetics indicates that endogenous insulin reaction plays an essential role in the development of amyloid. Moreover, a multicenter study aimed to estimate the prevalence of amyloid deposits in a group of patients with and without diabetes. Patients whose autopsy was performed within the first $24 \mathrm{~h}$ of death were included in the study. Data regarding the plasma glucose levels, hemoglobin A1C, total cholesterol, triglyceride, low-density lipoproteins, high-density lipoproteins, body mass index, and the sufficiently harvested pancreatic tissue were available. The presence of amyloid deposits was identified as being higher $(39.6 \%)$ in patients with diabetes than in non-diabetic patients (3\%). In diabetic patients the presence of amyloid was associated with a higher body mass index and poor glycemic control. The study showed a higher frequency of pancreatic fibrosis and fat infiltration in diabetic patients with amyloid deposits compared to those without amyloid. Pancreatic atherosclerosis was identified in all diabetic patients enrolled in the study [53]. Studies have shown that the formation of amyloid deposits in beta cells is a diabetogenic factor and that there is a close relationship between them and the development of diabetes. However, the role of island amyloid in diabetes is still being debated. There is no certainty whether the island amyloid is directly involved, or it is just the consequence of the disease. It is also unknown if diabetic hyperglycemia and insulin resistance induce amyloid deposition in the islets and brain [54].

Using brain samples from the temporal cortex from patients confirmed with AD at autopsy and from non-AD patients, researchers investigated the simultaneous presence of IAPP and amyloid beta in the human brain. Western blot analysis showed that samples from AD patients contained 1.4 times higher concentrations of IAPP than non-AD samples. Beta amyloid was detected in higher concentrations in AD samples than in non-AD samples [55]. Jackson et al. [56] investigated brain samples from patients with diabetes and dementia (vascular dementia or AD), patients with $\mathrm{AD}$ and no history of diabetes, and samples from healthy people. The immunohistochemically examination of the gray matter of the temporal lobe from diabetic patients with dementia revealed many amylin plaques. Amylin deposits were identified in brain samples from patients with AD and no diabetes. In these samples, the distribution of amylin deposits was like that of the group of samples from patients with diabetes mellitus and dementia. In the control group, rare amylin deposits were found in the brain parenchyma and in blood vessels. Pancreatic amylin is being accumulated in the brain as independent plaques or its co-primes with beta amyloid to form complex amyloid-beta amyloid plaques. The latter contributes to the neurodegeneration of the patient with diabetes mellitus. In a clinical study, Janson et al. [34] investigated the prevalence of diabetes in patients with AD and in patients without AD. The prevalence of diabetes was higher in patients with $\mathrm{AD}$ versus the control group (34.6\% vs. $18.1 \%$ ). In parallel, the authors performed a pathological study on brain and pancreas samples. The frequency and the extent of amyloid were higher in the AD group compared to the non-AD control group. Amyloid deposits were also higher in patients with diabetes compared with the non-diabetes group. No differences were found regarding the density of diffuse or neuritic plaques in the patients with diabetes compared with the control group non-diabetics.

Insulin is the major gluco-regulator of energy homeostasis as well as a modulator of brain activity, a hormone that enhances glucose uptake and metabolism in neurons and glial cells [57]. From a physiological point of view, insulin binds to insulin receptors (IR), triggering the phosphorylation of the insulin receptor substrate (IRS1) involved in the activation of phosphatidylinositol 3 kinase (PI3K) at the brain level by modulating synaptic plasticity and cognition, with neurotrophic, neuro-modulatory, and neuroprotective effects $[58,59]$.

Among the common features of $\mathrm{AD}$ and diabetes, an etiological factor in $\mathrm{AD}$ is the reduced cellular reaction to insulin, a phenomenon highlighted in a post-mortem study when the causes and consequences of insulin resistance at the brain level were analyzed, especially regarding the hippocampus, the dentate gyrus, and the subiculum, favoring the emergence of a marked early pathology, with this insulin resistance of the brain being a frequent feature in AD patients [60]. Insulin reaches the brain through the blood-brain barrier (BBB) to take part in various cognitive 
processes. Insulin synthesis and secretion play an important role in maintaining glucose levels within normal limits. In this regard, some researchers have observed that glucose uptake and metabolism in the brain are regulated by insulin, and its imbalances causes the disruption of energy metabolism with the production of reactive oxygen species (ROS) and mitochondrial dysfunction, followed by activation of the pro-apoptotic and inflammatory cascade, A $\beta$-forming APP cleavage [61]. Moderate insulin concentrations at the brain level have neurotrophic properties, and elevated concentrations are associated with the reduced amyloid clearance [62]. The brain insulin deficiency in AD appears to be mediated by the activity of two enzymes: the insulin-degrading enzyme (IDE) and the calcineurin 1 regulator (RCAN1). The fact that IDE may degrade insulin, amylin, and A $\beta$ suggests that AD may be linked to diabetes via chromosome 10 and the finding that $A \beta$ plaque size correlates inversely with IDE expansion and activity suggests that IDE deficiency may mediate plaque accumulation and cognitive impairment in AD [63]. The concept of insulin resistance was described in 1940 and since then a clear picture has emerged about its involvement in AD. Moreover, insulin resistance, and lipid and carbohydrate metabolism lead to A $\beta$ aggregation and memory impairment $[51,64]$. Cognitive defects in diabetes are associated with insulin resistance that affects psychomotor efficiency, attention, learning memory, mental flexibility, speed, and executive function of the brain. The basic pathophysiology of cognitive dysfunction in diabetes is not fully known and characterized. However, in recent years, several hypotheses have been proposed and research results have been published that validate such hypotheses. The theories underlying cognitive dysfunction are usually correlated with hyperglycaemia, vascular disease, hypoglycaemic episodes, insulin resistance, and amyloid $[65,66]$. Defective insulin secretion by pancreatic $\beta$-cells and insulin sensitivity are the main causes of diabetes mellitus type 2 . In addition to peripheral insulin function, it also intervenes in the regulation of synaptic and neuronal function in the cortex, cerebellum, and hippocampus, as well as in the protection of neurons from brain death. It also acts on the enzyme for the elimination of $\beta$-site precursor protein (BACE1) and $\gamma$-secretase to regulate $A \beta$ levels and degrade excess $A \beta$ by modulating insulin-degrading enzyme [51]. Another study (Hisayama study) conducted between 1998-2003 in patients of both sexes suggested that histopathological features present in $\mathrm{AD}$ are associated with diabetes or insulin resistance on the basis of the relevant statistical data that have shown that hyperglycaemia and hyperinsulinemia are major risk factors in the development of amyloid plaques [67]. Insulin resistance appears due to the reduced ability of the insulin receptor to respond to insulin stimulation, this resistance being a major feature of diabetes that could be detected long before the clinical signs of the disease [68]. There is evidence to support the fact that, with age, insulin levels increase, and that hyperinsulinemia is associated with a functional decline in the central nervous system (CNS). Some studies in older men have reported that men with the highest insulin levels, when performing the Mini-Mental State test, had $25 \%$ more errors compared to those with very low insulin levels [69]. The accumulation of amylin in the pancreas can decrease the level of insulin, which will lead to disruptions in carbohydrate metabolism (hyperglycemia) and will promote the development of neurodegenerative disorders [70]. The influence of high glucose levels on cognitive impairment was highlighted in the ACCORD-MIND study, which by assessing glycosylated hemoglobin (HbA1c) could detect the negative impact on cognitive tests [71]. It is possible that chronic exposure of the brain to high glucose levels may hasten cognitive decline, which was observed in post-mortem studies carried out with patients with AD where amyloid plaques and metabolic degradation products associated with hyperglycemia were found [72,73]. Hyperglycemia levels most likely due to poor insulin synthesis could be corrected by using mediational therapies involved in increasing insulin levels. There are many clinical trials in AD patients who support these assertions and have shown that medication used to increase insulin levels has improved the condition of patients with cognitive impairments [74]. Recently, more and more attention has been devoted to the role played by glycation of proteins in promoting amyloid aggregation and cell toxicity [75]. In hyperglycemic conditions, proteins are highly susceptible to non-enzymatic glycation, and this post-translational modification could differentially affect the aggregation process and amyloid formation in promoting, accelerating, and/or stabilizing on-pathway and off-pathway 
species [76]. The observation, according to which proteins from amyloid deposits such as A $\beta$-peptide, IAPP, tau, prions, and transthyretin can be glycated, indicates a direct relationship between protein glycation and amyloidosis [77]. Thus, in vitro and in vivo studies have shown that non-enzymatic glycation promotes the formation of amyloid fibrils in IAPP [78] and may stabilize the toxic oligomeric species related to neurotoxicity for both $A \beta$-peptide [79] and human insulin [80]. Glycation is a pathological process implicated in the chronic complications of diabetes and has been described to play a crucial role in normal aging process and pathogenesis of Alzheimer's disease $[77,81]$.

\section{The Influence of Amyloid- $\beta$ Aggregates on Diabetes Pathology and Islet Amyloid Polypeptide on Alzheimer's Disease in Animal Models}

The relevance of exploring these two amyloids may not be stressed enough given that pancreatic IAPP aggregation has been found in over $96 \%$ of autopsied diabetes individuals [82,83], and A $\beta$ plaques are constantly reported in the brain of the $\mathrm{AD}$ patients $[17,84]$. Cerebral insulin resistance has been highlighted to intensify A $\beta$ fibrillogenesis by increasing and clustering of GM1 ganglioside in the neuronal membranes [85] and cognitive decline [86]. In both humans and rodents affected by early $\mathrm{AD}$, insulin administration has been correlated with reduced amyloid accumulation and improved cognitive performance $[87,88]$. Preclinical induction of diabetes has been able to exacerbate tau pathology $[89,90]$. In addition, in murine models of $\mathrm{AD}$, chronic anti-diabetic therapy may reduce tau deposits and the $\beta$-amyloid plaque count by $40 \%-50 \%$ [91], and rescue spatial memory and recognition impairments [92]. Mostly in diabetic cases, low glucose brain metabolism, a negative effect of insulin deficiency or insulin resistance, could be the main culprit for the risk intensification of AD development.

Most clinical studies link diabetes to $\mathrm{AD}$, and diabetics have a twofold increased risk of developing $\mathrm{AD}[82,93,94]$, while another part of the studies suggest an inverse relationship [34]. Synthetic preformed fibrils of human IAPP 1 to 37 , or A $\beta 1$ to 42 (corresponding to $20 \mu \mathrm{g}$ of peptide in $100 \mathrm{~mL}$ of $0.15 \mathrm{~mol} / \mathrm{L}$ sodium chloride) intravenously injected into tail vein of human IAPP transgenic mice acted as a seed for IAPP in the islet of Langerhans. The findings showed not only a higher number of mice with islet amyloid, but also the number of islets with amyloid was substantially increased from $2.7 \%$ and $5 \%$ in animals inoculated with sodium chloride and human des-31,32 proinsulin, respectively, to $24.1 \%$ in individuals injected with human IAPP fibrils, and $15.2 \%$ in those with A $\beta$ fibrils. Morphological evaluation using proximity ligation assay and Western blot analysis of IAPP and $A \beta$ in islets of diabetics and cerebral $A \beta$ deposits of AD cases revealed co-localization of IAPP and $A \beta$ in brain and cerebrovascular amyloid deposits, while $A \beta$ reactivity was not identified in any amyloid aggregates of endocrine pancreas. In this study it could not be identified if the IAPP found in the brain was locally formed or derived from pancreatic B cells. Taken together, the heterologous seeding between IAPP and A $\beta$ highlighted here may support a molecular link between these chronic amyloidogenic conditions [55].

Previous studies have shown that inoculation of $A D$ brain tissue extracts could be used for experimental induction of $A \beta$ plaques and cerebral beta-amyloid angiopathy in non-human primates [95] and transgenic APP mice [96,97], although inoculation of preformed purified and synthetic fibrils from $A \beta 40 / 42$ was less effective $[98,99]$. The detection of multiple mouse and human A $\beta 42 / 40$ variants in cerebral amyloid deposits formed in human APP-London transgenic mice offered evidence that APP mice may be processed into A $\beta$ [100]. Therefore, it can conclude that the conditions required for $A \beta$ fibrillation are found in transgenic IAPP mice, but despite this, mice inoculated with A $\beta$ fibrils developed only IAPP amyloid in the islet of Langerhans. In an attempt to clarify the mechanism of cerebral beta-amyloid induction by intraperitoneal administration of $A \beta$-comprising brain extracts in preclinical models, Eisele et al. [101] used three APP transgenic mouse strains that vary in levels of transgene expression in the brain (APP23 mice and APP23 mice missing murine APP) and also to some extent in systemic organs (R1.40 mice). Remarkably, two intraperitoneal injections of $100 \mu \mathrm{L}$ of brain extracts resulted in an earlier and strong induction of cerebral amyloid in APP23 
strain than in R1.40 host. These data are consistent with a nearly five- to sevenfold overexpression of human APP in the brain of APP23 mice [102] compared to the threefold overexpression of human APP in the R1.40 mice [103]. Despite a peripheral expression of A $\beta$-precursor protein, R1.40 mice never developed beta-amyloid outside the brain. These findings reflected a more complex mechanism for $A \beta$ seeding, and the lack of $A \beta$ deposited in islet amyloid may be directly dependent on low or no $A \beta$ production in peripheral tissue.

To elucidate the pathophysiological relationship between diabetes and $\mathrm{AD}$, Takeda and co-workers [104] developed two mouse models that reveal the pathological aspects of both conditions. They crossed a murine model of AD (APP23) with two strains of diabetic mice (ob/ob and Nagoya-Shibata-Yasuda (NSY) mice) and explored their brain and metabolic pathology. In double transgenic APP $\times$ ob/ob mice, the onset of diabetes caused an exacerbation of Alzheimer-like cognitive impairment, without an increase of the $A \beta$ load in the brain, supporting the notion that Alzheimer pathology could promote diabetes. APP $\times$ NSY fusion mice displayed marked glucose intolerance compared to their control groups. Notably, in both mouse models, these findings were associated with cerebrovascular inflammation and an important brain amyloid angiopathy. However, this research did not fully establish whether AD could accelerate the development of the diabetic phenotype.

Over time, epidemiological, clinical and basic research has revealed a direct relationship between diabetes and $\mathrm{AD}$. To test the hypothesis that $\mathrm{AD}$ would determine the onset of diabetes, Jiménez-Palomares et al. [105] generated a new transgenic mouse model. Thus, they cross-linked transgenic AD APPswe/PS1dE9 mice with $(\mathrm{db} /+)$ mice, partially deficient in leptin signaling, and monitored their body weight, and insulin and plasma glucose levels. Phenotypic characterization of glucose metabolism was performed using glucose and insulin tolerance tests. Histomorphometry was used to analyze the cell mass, number of islets, and their volume. Compared with the control group (APP/PS1 mice with co-expression in mice with intact leptin receptor signaling), the novel developed mouse model (APPswe/PS1dE9 $\times$ db/+) showed noneating hyperglycemia, hypercholesterolemia, and hyperinsulinemia, with no alterations in body weight. In contrast, fasting glucose homeostasis and cholesterol levels remained unchanged between APP/PS1 co-expression in $\mathrm{db} /+$ mice and their control. Concurrent with modified glucose metabolism, APPswe/PS1dE9 $\times \mathrm{db} /+$ mice led to glucose intolerance, insulin resistance, and altered insulin signaling. These results were paralleled with an increase in $\beta$-cell mass expansion, providing at the same time experimental evidence that supports the idea that abnormal $A \beta$ production could be a mechanistic link that underlies pathology of insulin resistance and diabetes in Alzheimer's disease.

To more fully clarify neuro-inflammatory alterations related with diabetes that could drive AD pathology, Sankar and co-workers [70] quantified cortical modifications in cytokine proteins in three different models of mice, with metabolic changes relevant to diabetes combined with a mouse model of AD (APP/PS1). Multiplexed immunoassay showed that pathology associated with either pre-diabetes, $\mathrm{db} / \mathrm{db}$, or streptozotocin models led to the upregulation of a comprehensive profile of cytokines, comprising chemokines (macrophage inflammatory protein- 1 alpha, $\mathrm{MIP}-1 \alpha$; monocyte chemoattractant protein-1, MCP-1; and macrophage inflammatory protein-1 beta, MIP-1 $\beta$ ) and proinflammatory cytokines (IL- $1 \alpha$; interferon gamma, IFN- $\gamma$; and IL-3). Moreover, the APP/PS1 $\times \mathrm{db} / \mathrm{db}$ mice model presented circulating levels of $\mathrm{A} \beta 40 / 42$, glucose, and insulin correlated with brain cytokine expression, supporting a robust relationship between peripheral alterations and cerebral pathology. In this context, the authors suggest that since most of the highlighted cytokines stimulate neuronal damage, tau, and A $\beta$ pathology, as well as breakdown of the blood-brain barrier, neuro-inflammation may modulate the effects of diabetes on the pathogenesis of AD.

In translational research, the casual or causal relationship between diabetes and $\mathrm{AD}$ in the past decade has been intensively studied in murine AD models on hyperlipidemia polygenic backgrounds, intake of ultrahigh-fat diets [104-108], or streptozotocin-induced b-cell death acute models [109, 110]. However, these models due to the incapacity of rodents to aggregate IAPP did not reveal amyloid IAPP deposition. To study the interconnection between these amyloidogenic diseases, 
animal models have been generated that co-express both human A $\beta$ and IAPP pathologies, able to closely resemble the clinical presentation of diabetes, permitting a more precise replication of insulin-signaling defects that appears in humans. Apolipoprotein E (ApoE), a constituent of the deposits, has been identified in the islet cells as having a significant role in disorders of lipid metabolism, which are often related with diabetes [111,112]. In addition, the most common occurring isoform, ApoEO4, has been involved in plaque formation in patients with AD. However, no association has been found between ApoE genotype and the degree of islet amyloidosis in post-mortem specimens or with severity of diabetes [113]. An association between diabetes, ApoE genotype, and dementia has been identified in Polynesian/American men, but the degree of islet amyloidosis was not determined [93]. Studies by Wijesekara et al. [114] have shown that A $\beta$ and IAPP are crucial features in the overlapping pathologies of diabetes and AD. When they crossed AD-related human APP transgenic mice to human IAPP homozygote animals, this study found that the novel double transgenic mouse model was markedly hyperglycemic, exhibiting severe insulin resistance and glucose intolerance, accompanied by exacerbated brain pathology. IAPP and A $\beta$ amyloid co-deposition significantly elevated tau phosphorylation, and a decrease in pancreatic b-cell mass was detected in islets. In 24-week-old mice, both increased tau phosphorylation, plaque load, and hippocampal total A $\beta 42$ levels, and decreased insulin levels and signaling were complemented by widespread synaptic loss and reduced neuronal counts. In addition, synthetic $A \beta 42$ immunization to verify whether peripheral $A \beta$ contributes to insulin resistance has been associated with the rescue of hyperglycemia and peripheral insulin resistance, suggesting an important role for $A \beta$ in the pathogenesis of diabetes for people predisposed to $\mathrm{AD}$.

The precise relationship between amyloid peptides is not currently known, but it is highly likely that formation and accumulation of one protein may promote the misfolding and aggregation of another one, indicating a possible cross-seeding effect. Misfolded IAPP can be formed and deposited in the brain of diabetes and $A D$ patients [56], whereas $A \beta$ and tau proteins can be detected in pancreatic islets in diabetes [83]. The effect of the co-existence of both IAPP and A $\beta$ in vivo and the intensification of brain amyloid deposition by exogenous use of IAPP aggregates in transgenic AD mouse models was investigated by Moreno-Gonzalez et al. [115]. The authors generated and characterized models of double transgenic mice named IAPP ${ }^{+/-} \times \mathrm{APP}$ and $\mathrm{IAPP}^{+/+} \times \mathrm{APP}$, comprising one copy of mutant human APP gene (APPSwe $\left.{ }^{+-}\right)$and one $\left(\mathrm{IAPP}^{+-}\right)$or two $\left(\mathrm{IAPP}^{+/+}\right)$human IAPP copies. Transgenic mice expressing both IAPP and $A \beta$ proteins displayed an exacerbation of both plaque density and $A \beta$ burden in the brain as opposed to transgenic AD animals or transgenic AD mice with type-1 diabetes. Interestingly, in the parenchymal deposits of the brain, IAPP polypeptide co-localized with amyloid plaques, suggesting that these peptides can interact directly, aggravating the disease. Similar results were also observed in transgenic rats overexpressing human IAPP in the pancreas, which also showed IAPP deposits in the cerebral parenchyma [116]. In addition, pancreatic tissue examination from mice over-expressing the mutant human APP gene revealed a substantially higher IAPP load, signifying that A $\beta$ pathology may also stimulate pancreatic IAPP aggregation. Furthermore, intracerebral injection of aggregated IAPP homogenates into the APP mice brains led to a more intense AD pathology accompanied by severe memory deficits than untreated animals. Collectively, these data suggest that IAPP and A $\beta$ may interrelate by cross-seeding, offering a new potential explanation for the higher risk of $\mathrm{AD}$ in people affected by diabetes [115]. In addition, the results of Moreno-Gonzalez et al. [115] are supported by an earlier observation in non-human primates that spontaneously develop both $\mathrm{AD}$ and diabetes conditions, which presented accelerated $\mathrm{A} \beta$ pathology compared to non-diabetic monkeys [117]. This research supports the conclusion that the coexistence of A $\beta$ and IAPP in the same patient and the distinctive features of these amyloid peptides contribute to accelerate or increase disease phenotypes. 


\section{Relevance of Molecular Interaction between Islet Amyloid Polypeptide and Amyloid- $\beta$ Peptide for Novel Therapeutics}

Given the poor epidemiological forecast, research policies, and strategies, as well as the large body of reports that diabetes and associated traits increase the risk for developing AD, there has been an extraordinary interest in exploring whether the use of antidiabetic compounds could impact the risk of dementia, and whether these drugs may be utilized to prevent or treat Alzheimer's disease. Thus, dozens of studies have been undertaken to evaluate the extent to which antidiabetic treatments could impact brain pathology (Table 2), especially AD features, with the most part of studies targeting potential benefits on amyloid pathology [118,119], cognitive function [120-122], tau pathology [123,124], neuroinflammation [125], oxidative stress [126], neurogenesis [127], and synapses [128,129].

Table 2. Comparative efficiency and acceptability of antidiabetic compounds for Alzheimer's disease.

\begin{tabular}{|c|c|c|c|}
\hline $\begin{array}{l}\text { Antidiabetic } \\
\text { Medication }\end{array}$ & Experimental Model & Findings & References \\
\hline \multicolumn{4}{|c|}{ Biguanides } \\
\hline \multirow{5}{*}{ Metformin } & $\begin{array}{l}\text { mouse neuroblastoma cell lines under } \\
\text { sustained hyperinsulinemic conditions } \\
\text { treated with different concentrations of } \\
\text { metformin }(0.4-3.2 \mathrm{mM})\end{array}$ & $\begin{array}{l}\text { resensitization of insulin signaling; } \\
\text { prevention of the molecular and } \\
\text { pathological alterations detected in } \mathrm{AD} \\
\text { neurons }\end{array}$ & [130] \\
\hline & $\begin{array}{l}\text { transgenic APPswe/PSd1E9 mouse model } \\
\text { of AD; intraperitoneal delivery of } 200 \\
\mathrm{mg} / \mathrm{kg} \text { metformin for } 14 \text { days }\end{array}$ & $\begin{array}{c}\text { amelioration of spatial memory deficits, } \\
\text { neural cellular proliferation; in the } \\
\text { cortex and hippocampus, reduction of } \\
\text { local inflammation, decrease of } A \beta \\
\text { plaque deposition }\end{array}$ & [119] \\
\hline & $\begin{array}{l}\text { PDAPP (J9) mouse model of AD; } 350 \\
\text { mg/kg/day metformin delivered in } \\
\text { drinking water for several months }\end{array}$ & $\begin{array}{l}\text { attenuation of memory impairment in } \\
\text { female subjects and intensification of it } \\
\text { in males }\end{array}$ & [131] \\
\hline & $\begin{array}{c}\text { longitudinal aging study in adults with } \\
\text { diabetes }\end{array}$ & $\begin{array}{c}\text { long-term metformin therapy (over } 6 \\
\text { years) could diminish the risk of } \\
\text { developing AD }\end{array}$ & [132] \\
\hline & $\begin{array}{l}\text { case-control study, older adults with an } \\
\text { incident diagnosis of AD; } 1-9,10-29 \text {, } \\
30-59 \text {, or } \geq 60 \text { metformin prescriptions }\end{array}$ & $\begin{array}{l}\text { long-term treatment ( } 60 \text { or more } \\
\text { prescriptions) has been correlated with a } \\
\text { slight augmented risk of developing AD }\end{array}$ & [133] \\
\hline \multicolumn{4}{|c|}{ Sulphonylureas } \\
\hline Glibenclamide & $\begin{array}{c}\text { A } \beta 25-35 \text {-induced rat AD model; } 6 \\
\mathrm{mg} / \mathrm{kg} / \text { day of glibenclamide for } 20 \text { days } \\
\text { by gavage }\end{array}$ & $\begin{array}{l}\text { reduction of A } \beta 25-35 \text {-treated } \\
\text { behavioral anomalies }\end{array}$ & [134] \\
\hline \multicolumn{4}{|c|}{$\begin{array}{ll}\text { Thiazolidinediones } \\
\end{array}$} \\
\hline \multirow{5}{*}{ Pioglitazone } & $\begin{array}{l}\text { meta-analysis of randomized clinical } \\
\text { trials; } 15 \text { to } 30 \mathrm{mg} \text { of pioglitazone, as } \\
\text { adjunct therapy for } \mathrm{AD}\end{array}$ & $\begin{array}{l}\text { doses of } 15 \text { to } 30 \mathrm{mg} \text { pioglitazone but } \\
\text { not } 45 \mathrm{mg} \text { improve cognitive capacity }\end{array}$ & [135] \\
\hline & $\begin{array}{l}\text { transgenic APPswe/PSEN1dE9 AD mouse } \\
\text { model; combined therapy with } 0.03 \\
\mathrm{mg} / \mathrm{kg} / \text { day of leptin intranasal delivery }+ \\
\text { intraperitoneal administration of } 10 \\
\mathrm{mg} / \mathrm{kg} / \text { day pioglitazone for } 2 \text { weeks }\end{array}$ & $\begin{array}{l}\text { decrease of spatial memory } \\
\text { impairments and brain } A \beta \text { levels }\end{array}$ & [122] \\
\hline & $\begin{array}{c}\text { APPV717I transgenic mice, a model for } \\
\text { AD; acute } 7 \text { days gavage therapy with } 40 \\
\mathrm{mg} / \mathrm{kg} / \text { day of pioglitazone } \\
\text { controlled trial in cases with mild }\end{array}$ & $\begin{array}{l}\text { reduction of soluble } A \beta 1-42 \text { peptide } \\
\text { levels by } 27 \% \text { and glial inflammation }\end{array}$ & [125] \\
\hline & $\begin{array}{c}\text { Alzheimer's disease and an } \\
\text { accompanying diagnosis of diabetes; } \\
\text { daily doses of } 15-30 \mathrm{mg} \text { pioglitazone for } 6 \\
\text { months }\end{array}$ & $\begin{array}{l}\text { cognitive and functional improvements } \\
\text { and stabilization of the disease in } \\
\text { diabetics with } \mathrm{AD}\end{array}$ & [136] \\
\hline & $\begin{array}{l}\text { controlled pilot trial in individuals with } \\
\text { AD without diabetes; daily } 45 \mathrm{mg} \text { of } \\
\text { pioglitazone }\end{array}$ & $\begin{array}{l}18 \text { months of pioglitazone therapy were } \\
\text { well tolerated by patients, but no } \\
\text { important efficacy data were detected }\end{array}$ & [137] \\
\hline
\end{tabular}


Table 2. Cont.

\begin{tabular}{|c|c|c|c|}
\hline $\begin{array}{l}\text { Antidiabetic } \\
\text { Medication }\end{array}$ & Experimental Model & Findings & References \\
\hline \multirow{4}{*}{ Rosiglitazone } & $\begin{array}{c}\text { meta-analysis of randomized clinical } \\
\text { trials; } 2 \text { to } 8 \text { mg of rosiglitazone, as } \\
\text { adjunct therapy for mild to moderate } \mathrm{AD} \\
\text { patients }\end{array}$ & pro-cognitive effects & [135] \\
\hline & $\begin{array}{l}\text { pilot study that randomized individuals } \\
\text { with AD or amnestic mild cognitive } \\
\text { damage }\end{array}$ & $\begin{array}{l}\text { better delayed recall and selective } \\
\text { attention }\end{array}$ & [138] \\
\hline & $\begin{array}{l}\text { large study in population with mild to } \\
\text { moderate } \mathrm{AD} ; 2,4 \text {, or } 8 \mathrm{mg} \text { of } \\
\text { rosiglitazone for } 6 \text { months }\end{array}$ & $\begin{array}{l}\text { in week } 24 \text { an improvement }(-2.9 \\
\text { points) of cognition in apolipoprotein } \\
\text { Ee4-negative people treated with } 8 \mathrm{mg} \\
\text { of rosiglitazone was registered }\end{array}$ & [139] \\
\hline & $\begin{array}{l}\text { phase III trials of rosiglitazone in AD; } 2 \\
\text { mg or } 8 \text { mg rosiglitazone for } 48 \text { weeks, as } \\
\text { adjunctive agent to ongoing acetylcholine } \\
\text { esterase inhibitors }\end{array}$ & $\begin{array}{l}\text { rosiglitazone did not lead to an } \\
\text { improvement in cognition or overall } \\
\text { function }\end{array}$ & [140] \\
\hline \multicolumn{4}{|c|}{ Glucagon-like peptide-1 receptor agonists } \\
\hline \multirow{3}{*}{ Lixisenatide } & $\begin{array}{l}\text { transgenic APPswe } / \text { PSd1E9 mouse model } \\
\text { of AD; intraperitoneal injection with } 1 \text { or } \\
10 \mathrm{nmol} / \mathrm{kg} \text { of compound for } 10 \text { weeks }\end{array}$ & $\begin{array}{l}\text { several biomarkers have been improved } \\
\text { such as learning, inflammation, or plate } \\
\text { loading }\end{array}$ & [129] \\
\hline & $\begin{array}{l}\text { cell culture, } 100 \mu \mathrm{M} \text { of lixisenatide were } \\
\text { applied } 24 \mathrm{~h} \text { before } \mathrm{A} \beta 25-35 \text { application } \\
\text { rat model of } \mathrm{AD} ; 5 \mathrm{nmol} / \mu \mathrm{L} \text { of } \\
\text { lixisenatide before intrahippocampal } \\
\text { application of } \mathrm{A} \beta 25-35(5 \mathrm{nmol} / \mu \mathrm{L})\end{array}$ & $\begin{array}{c}\text { reversal A } \beta 25-35 \text {-triggered cytotoxicity, } \\
\text { normalization of intracellular calcium } \\
\text { levels } \\
\text { prevention of memory loss caused by } \\
\text { amyloid intracerebroventricular } \\
\text { injection }\end{array}$ & [141] \\
\hline & $\begin{array}{l}\text { transgenic APP/PS1/tau mouse model of } \\
\text { AD; daily intraperitoneal injection of } 10 \\
\text { nmol/kg lixisenatide for } 60 \text { days }\end{array}$ & $\begin{array}{l}\text { reduction of amyloid plaques, } \\
\text { neuroinflammation, and neurofibrillary } \\
\text { tangles }\end{array}$ & [142] \\
\hline Dulaglutide & $\begin{array}{l}\text { intracerebral injection of } \\
\text { streptozotocin-induced mouse AD-like } \\
\text { condition; } 0.6 \mathrm{mg} / \mathrm{kg} / \text { week of dulaglutide } \\
\text { with intraperitoneal delivery for } 4 \text { weeks }\end{array}$ & $\begin{array}{c}\text { amelioration of learning and memory } \\
\text { deficits }\end{array}$ & [143] \\
\hline \multirow[b]{5}{*}{ Liraglutide } & $\begin{array}{l}\text { transgenic APPswe/PSd1E9 mouse model } \\
\text { of AD; intraperitoneal injection with } 2.5 \\
\text { or } 25 \mathrm{nmol} / \mathrm{kg} \text { of drug for } 10 \text { weeks } \\
\text { methylglyoxal-induced mouse }\end{array}$ & $\begin{array}{l}\text { improvement of learning, reduction of } \\
\text { amyloid plaque deposits by } 40 \%-50 \% \text {, } \\
\text { and decrease inflammatory response }\end{array}$ & [129] \\
\hline & $\begin{array}{l}\text { Alzheimer-like condition; daily } \\
\text { subcutaneous administration of } 25 \\
\text { nmol/kg liraglutide for } 2 \text { months }\end{array}$ & $\begin{array}{l}\text { attenuation of hippocampal damage } \\
\text { and cognitive deficits in C57BL/6J mice }\end{array}$ & [144] \\
\hline & $\begin{array}{l}\text { cell culture; liraglutide }(300 \mathrm{~nm}) \text { was } \\
\text { added to cultures } 40 \text { min before } \mathrm{A} \beta \\
\text { oligomers }\end{array}$ & $\begin{array}{l}\text { reduction of } A \beta \text { oligomer-induced } \\
\text { synaptotoxicity, protective effects on } \\
\text { synapses; }\end{array}$ & \multirow{3}{*}{ [121] } \\
\hline & $\begin{array}{c}\text { A } \beta \text { oligomers-induced AD mouse model; } \\
\text { daily intraperitoneal injections of } \\
\text { liraglutide }(25 \mathrm{nmol} / \mathrm{kg}) \text { for } 7 \text { days }\end{array}$ & $\begin{array}{l}\text { prevention and reversal of cognitive } \\
\text { abnormalities, and insulin receptor loss } \\
\text { produced by intracerebroventricular } \\
\text { injection of } A \beta \text { oligomers; }\end{array}$ & \\
\hline & $\begin{array}{l}\mathrm{A} \beta \text { oligomer-induced non-human } \\
\text { primate model of } \mathrm{AD} \text {; subcutaneous } \\
\text { delivery of liraglutide }(0.006 \mathrm{mg} / \mathrm{kg} / \text { day } \\
\text { for the first week and } 0.012 \mathrm{mg} / \mathrm{kg} \\
\text { thereafter) for } 24 \text { days }\end{array}$ & $\begin{array}{c}\text { the agent was less effective, but still } \\
\text { provided partial protection against } \\
\text { insulin resistance loss; synapses and } \\
\text { phosphorylation of tau }\end{array}$ & \\
\hline
\end{tabular}


Table 2. Cont.

\begin{tabular}{|c|c|c|c|}
\hline $\begin{array}{l}\text { Antidiabetic } \\
\text { Medication }\end{array}$ & Experimental Model & Findings & References \\
\hline & $\begin{array}{l}\mathrm{A} \beta \text { protein-induced rat model of } \mathrm{AD} ; 2 \\
\mu \mathrm{L} \text { liraglutide trough intrahippocampal } \\
\text { administration }\end{array}$ & $\begin{array}{c}\text { liraglutide pre-therapy remarkably } \\
\text { protected against } A \beta \text {-induced damage } \\
\text { of spatial memory and long-term } \\
\text { potentiation }\end{array}$ & [145] \\
\hline & $\begin{array}{c}\text { transgenic } 3 \times T g-A D \text { female mice; } 0.2 \\
\mathrm{mg} / \mathrm{kg} / \text { day of liraglutide, intraperitoneal } \\
\text { injections }\end{array}$ & $\begin{array}{c}\text { reduction of cortical A } \beta 1-42 \text { levels, } \\
\text { partial attenuation of cerebral estradiol, } \\
\text { inflammation, and oxidative/nitrosative } \\
\text { stress }\end{array}$ & [146] \\
\hline & $\begin{array}{l}\text { a pilot clinical trial in } \mathrm{AD} \text { patients lasting } \\
26 \text { weeks; in the first week, the drug was } \\
\text { daily delivered subcutaneously at a dose } \\
\text { of } 0.6 \mathrm{mg} \text {; hereafter } 1.2 \mathrm{mg} \text { daily for } \\
\text { another week before finally increasing to } \\
1.8 \mathrm{mg} \text { daily }\end{array}$ & $\begin{array}{l}\text { prevention of brain glucose metabolism } \\
\text { decline; there were no important } \\
\text { cognitive changes compared with } \\
\text { placebo group }\end{array}$ & [147] \\
\hline \multicolumn{4}{|c|}{ Dipeptidyl peptidase-4 inhibitors } \\
\hline Saxagliptin & $\begin{array}{c}\text { intracerebral injection of } \\
\text { streptozotocin-induced rat model of } \mathrm{AD} ; \\
0.25,0.5 \text {, and } 1 \mathrm{mg} / \mathrm{kg} \text { of saxagliptin } \\
\text { administered orally for } 60 \text { days }\end{array}$ & $\begin{array}{l}\text { reduction of amyloid plaque formation, } \\
\text { a marked decrease of A } \beta 42 \text { level, } \\
\text { and phosphorylation of tau protein; } \\
\text { total reversal of cognitive impairments }\end{array}$ & [148] \\
\hline \multirow{3}{*}{ Vildagliptin } & $\begin{array}{l}\text { intracerebral injection of } \\
\text { streptozotocin-induced rat model of } \mathrm{AD} ; \\
\text { daily oral doses of } 2.5,5 \text {, and } 10 \mathrm{mg} / \mathrm{kg} \\
\text { vildagliptin for } 30 \text { days }\end{array}$ & $\begin{array}{l}\text { attenuation of } A \beta \text {, phosphorylation of } \\
\text { tau protein, and inflammatory markers }\end{array}$ & [149] \\
\hline & $\begin{array}{c}\mathrm{A} \beta \text { protein-induced rat model of } \mathrm{AD} ; \\
\text { daily gavage of } 5 \text { or } 10 \mathrm{mg} / \mathrm{kg} \text { vildagliptin } \\
\text { for } 4 \text { weeks }\end{array}$ & $\begin{array}{l}\text { anti-apoptotic effect, attenuation of } \\
\text { memory abnormalities, reduction of tau } \\
\text { phosphorylation, and increase of } \\
\text { neurotrophic protein expression }\end{array}$ & [150] \\
\hline & $\begin{array}{c}\text { streptozotocin-induced rat diabetes } \\
\text { model associated cognitive decline; daily } \\
\text { gavage of } 5 \mathrm{mg} / \mathrm{kg} \text { vildagliptin for } 4 \\
\text { weeks }\end{array}$ & $\begin{array}{c}\text { prevention of memory impairment and } \\
\text { diminution of apoptosis in } \\
\text { hippocampal neurons }\end{array}$ & [151] \\
\hline Sitagliptin & $\begin{array}{l}\text { transgenic APPswe/PSd1E9 mouse model } \\
\text { of AD; daily gavage of } 5,10 \text {, and } 20 \\
\mathrm{mg} / \mathrm{kg} \text { sitagliptin for } 12 \text { weeks }\end{array}$ & $\begin{array}{l}\text { protective effect of cognitive function, } \\
\text { reduction of amyloid plaque deposits } \\
\text { much more obvious effects for the } 20 \\
\text { mg/kg sitagliptin dose-reduction of } \\
\text { nitrosative stress and inflammation } \\
\text { markers; an important diminution in } \\
\text { the number and area of APP and A } \beta \\
\text { deposition }\end{array}$ & [152] \\
\hline \multirow{2}{*}{ Linagliptin } & $\begin{array}{c}\text { 3xTg-AD mouse model of AD; daily oral } \\
\text { administration of } 5,10 \text {, and } 20 \mathrm{mg} / \mathrm{kg} \\
\text { linagliptin for } 8 \text { weeks }\end{array}$ & $\begin{array}{c}\text { improvement of cognitive performance; } \\
\text { reduction of } A \beta 42 \text { levels, but not } A \beta 40 ; \\
\text { diminution of tau phosphorylation and } \\
\text { neuroinflammation }\end{array}$ & [154] \\
\hline & $\begin{array}{c}\text { human neuroblastoma SK-N-MC cell } \\
\text { culture; exposure to } 10 \text { to } 100 \mu \mathrm{M} \\
\text { linagliptin for } 24 \mathrm{~h}\end{array}$ & $\begin{array}{l}\text { protection of cells against } A \beta \text {-induced } \\
\text { intracellular reactive oxygen species } \\
\text { accumulation and mitochondria } \\
\text { dysfunction }\end{array}$ & [155] \\
\hline \multicolumn{4}{|c|}{ Amylin analog } \\
\hline Pramlintide & $\begin{array}{l}\text { SAMP8 mice, a model of sporadic AD; } \\
\text { subcutaneous infusion of } 0.24 \mathrm{mg} / \mathrm{kg} / \text { day } \\
\text { pramlintide for } 5 \text { weeks }\end{array}$ & $\begin{array}{l}\text { may improve memory, decrease } \\
\text { neuroinflammation, and reduce } \\
\text { oxidative stress }\end{array}$ & [156] \\
\hline \multicolumn{4}{|c|}{ Sodium-glucose cotransporter 2 (SGLT-2) inhibitors } \\
\hline Canagliflozin & $\begin{array}{l}\text { scopolamine-induced rat model of } \\
\text { memory impairment; daily oral gavage of } \\
10 \mathrm{mg} / \mathrm{kg} \text { for } 2 \text { weeks }\end{array}$ & improvement of memory dysfunction & [157] \\
\hline
\end{tabular}


Table 2. Cont.

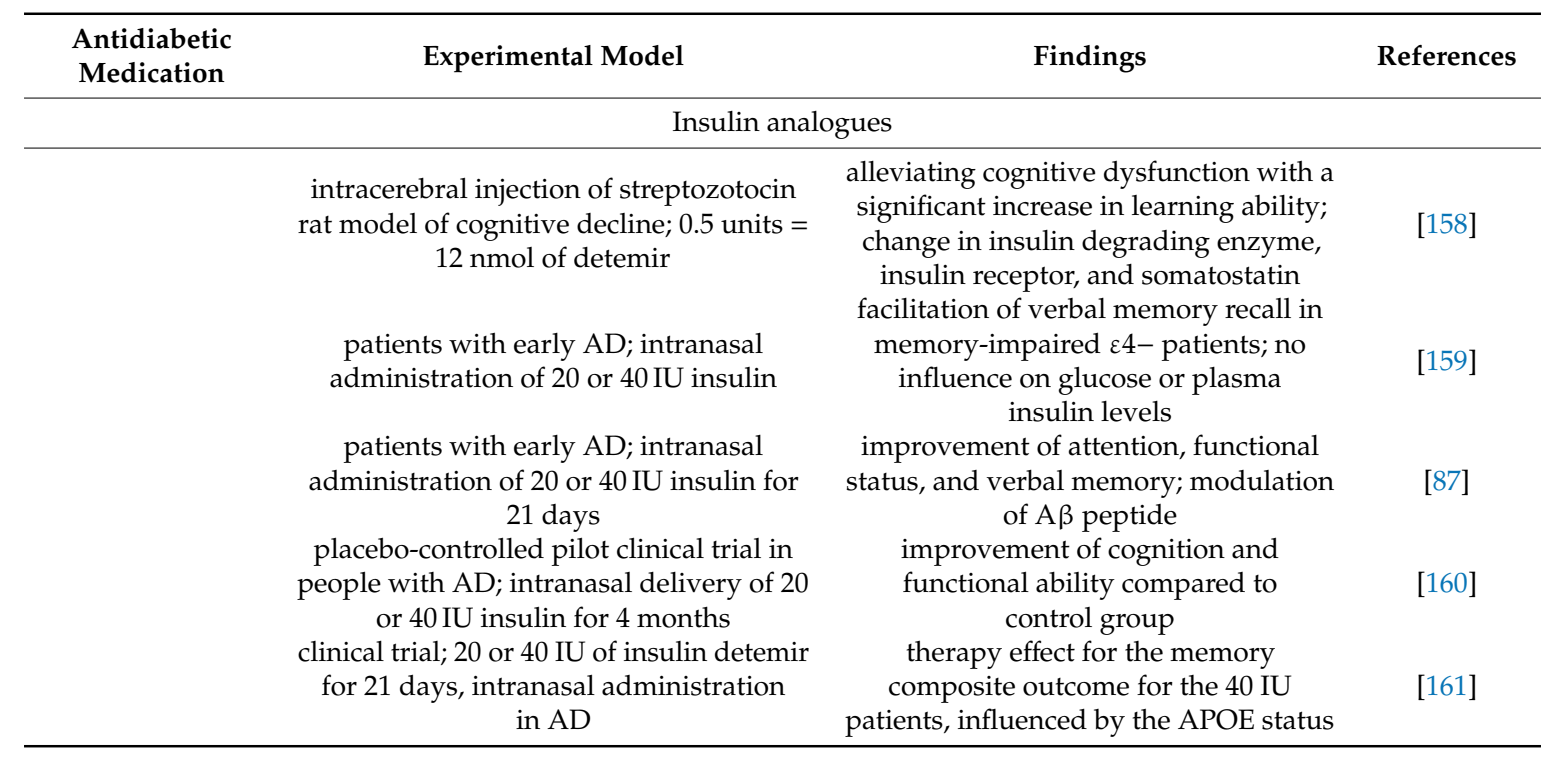

Although it has been highlighted that self-assembly of amyloid is related to pathogenesis of diabetes and $\mathrm{AD}$, to date, no amyloid inhibitor compounds have touched the clinic. This fact is in particulr due to the high conformational flexibility of the majority of amyloidogenic peptides, the interactions with high affinity between amyloid self-assembly, and the generous size of interfaces implicated. Moreover, supplementary challenges comprise the low BBB permeability, higher costs of production, possible immunogenicity of antibodies, and differential proteolytic stability [162]. Instead, macrocyclic peptides might be a reasonable alternative, because they most often combine highly promising "drug like properties", such as a great surface area, increase binding affinity, target selectivity, and high activity, improving the stability and cell permeability in biological fluids. Thus, a fairly large number of A $\beta 40 / 42$ peptide-based inhibitors or IAPP amyloidogenesis were derived from their target polypeptides [163-165]. Therefore, Spanopoulou et al. [166] designed macrocyclic peptides using IAPP-derived minimal recognition components as a new class of amyloid inhibitors of both IAPP and A $\beta 40 / 42$, or $A \beta 40 / 42$ alone, and revealed that chirality controls inhibitor selectivity. In addition, sequence optimization performed led to the detection of $A \beta 40 / 42$ selective macrocyclic peptides, with advanced proteolytic stability and human plasma and BBB crossing capacity, in vitro. Given to their promising properties, these compounds could aid as factors for macrocyclic peptide on the basis of anti-amyloid agents and scaffolds for the design and development molecule for directing amyloidogenesis in both diabetes and AD.

In vitro and in vivo exploration of molecular interaction between IAPP and A $\beta$ through self-/cross-interaction of protein misfolding can explain at least in part why there is a coexistence of the two amyloidogenic proteins in a single patient with a higher prevalence, as well as the augmented clinical features in some cases. Moreover, self-/cross-interaction mechanisms may explain why a part of conditions affiliated with protein formation and deposition are localized in aberrant regions of the affected body (e.g., IAPP co-localization with A $\beta$ in the pancreas and A $\beta$-IAPP co-localizing in the brain). The fact that IAPP and A $\beta$ are amyloids with common structural features permits the development and validation of new therapeutic approaches that target both proteins, offering more effective compounds. Additional data on the synergism of these conditions will likely alleviate the number of people affected by both diabetes and $\mathrm{AD}$, lowering the prevalence of both diseases and moreover ameliorating the economic burden of these chronic maladies in the world. 


\section{Concluding Remarks}

As the life expectancy of the population constantly increases along with the number of people living unhealthy lifestyles, the prevalence of age-related diseases, such as diabetes and AD, also increase. Thus, it is estimated that by 2050, the prevalence of these conditions will double or even triple. Although these statistics are at present quite unpleasant, current studies suggest that the existence of diabetes in a patient can increase the risk of AD by 2-5-fold, and the number of diabetics among the AD population is considerably increased in comparison to non-AD group controls that have been age-matched. Exploring further the role of molecular interaction between islet amyloid polypeptide and amyloid- $\beta$ peptide, two amyloidogenic proteins, as a common pathological feature in both diabetes and Alzheimer's disease, may offer novel directions in biomarker development and innovative therapeutic interventions that can prevent or reduce the occurrence of diabetes, as well as $\mathrm{AD}$. Since the pathological aspects attributable to these amyloidogenic proteins involve a wide range of organ systems usually related with diverse disciplines, multidisciplinary approaches by researchers and clinicians with different expertise and interests would be essential to move the field forward. All these efforts promise to promote our understanding of an understudied but crucially aspect of the pathobiology of diabetes in relation to AD.

Author Contributions: Conceptualization, G.D.S., D.B., V.B., D.C.A.; methodology, G.D.S., D.C.A., R.N.R., V.B., L.P., D.B., A.C.; writing—original draft preparation, G.D.S., D.B., D.C.A., R.N.R., L.P.; supervision and critical review of the manuscript, V.B., writing-review and editing, G.D.S., D.C.A. All the authors critically reviewed the manuscript. All authors have read and agreed to the published version of the manuscript.

Funding: This research did not receive any specific grant from funding agencies in the public, commercial, or not-for-profit sectors.

Conflicts of Interest: The authors declare no conflict of interest.

\section{Abbreviations}

AD, Alzheimer's disease; $A \beta$, amyloid- $\beta$ peptide; IAPP, islet amyloid polypeptide; APP, amyloid precursor protein; ADDLs, diffusible A $\beta$ derivatives or protofibrils; PSEN-1, presenilin-1; PSEN-2, presenilin-2; GM1, GM1 ganglioside; NSY mice, Nagoya-Shibata-Yasuda mice; AICD, cytoplasmic polypeptide; BACE1, beta-secretase 1; APPswe/PS1dE9 mice, APP/PS1 double transgenic mouse model of Alzheimer's disease over expressing amyloid precursor protein (APPswe), encoding the Swedish mutations at amino acids 595/596 and an exon-9-deleted human PS1 (PS1dE9); APPV717I mice, transgene containing human APP (isoform 695) with the London mutation as model for Alzheimer's disease and cerebral amyloid angiopathy; SAMP8 mice, senescence-accelerated prone mouse, a mouse model of sporadic AD; 3xTg-AD mice, triple transgenic mouse model of Alzheimer's disease; SGLT-2, sodium-glucose cotransporter 2 inhibitors; MRI, magnetic resonance imaging; IR, insulin receptors; IRS1, insulin receptor substrate; PI3K, phosphatidylinositol 3 kinase; ROS, reactive oxygen species; IDE, insulin-degrading enzyme; RCAN1, calcineurin 1 regulator; $\mathrm{BBB}$, blood-brain barrier; ApoE, apolipoprotein E.

\section{References}

1. Deture, M.A.; Dickson, D.W. The neuropathological diagnosis of Alzheimer's disease. Mol. Neurodegener. 2019, 5, 1-18. [CrossRef]

2. Magliano, D.J.; Islam, R.M.; Barr, E.L.M.; Gregg, E.W.; Pavkov, M.E.; Harding, J.L.; Tabesh, M.; Koye, D.N.; Shaw, J.E. Trends in incidence of total or type 2 diabetes: Systematic review. BMJ 2019, 366. [CrossRef] [PubMed]

3. Gregg, E.W.; Li, Y.; Wang, J.; Rios-Burrows, N.; Ali, M.K.; Rolka, D.; Williams, D.E.; Geiss, L. Changes in diabetes-related complications in the United States, 1990-2010. N. Engl. J. Med. 2014, 370, 1514-1523. [CrossRef] [PubMed]

4. Saeedi, P.; Petersohn, I.; Salpea, P.; Malanda, B.; Karuranga, S.; Unwin, N.; Colagiuri, S.; Guariguata, L.; Motala, A.A.; Ogurtsova, K.; et al. Global and regional diabetes prevalence estimates for 2019 and projections for 2030 and 2045: Results from the international diabetes federation diabetes atlas, 9th edition. Diabetes Res. Clin. Pr. 2019, 157. [CrossRef] [PubMed]

5. Bommer, C.; Sagalova, V.; Heesemann, E.; Manne-Goehler, J.; Atun, R.; Bärnighausen, T.; Davies, J.; Vollmer, S. Global economic burden of diabetes in adults: Projections from 2015 to 2030. Diabetes Care 2018, 41, 963-970. [CrossRef] 
6. Alzheimer's Disease International. World Alzheimer Report 2018-The State of the Art of Dementia Research: New Frontiers; Alzheimer's Disease International: London, UK, 2018.

7. Jack, C.R.; Bennett, D.A.; Blennow, K.; Carrillo, M.C.; Dunn, B.; Haeberlein, S.B.; Holtzman, D.M.; Jagust, W.; Jessen, F.; Karlawish, J.; et al. NIA-AA research framework: Toward a biological definition of Alzheimer's disease. Alzheimer's Dement. 2018, 14, 535-562. [CrossRef]

8. Li, L.; Hölscher, C. Common pathological processes in Alzheimer disease and type 2 diabetes: A review. Brain Res. Rev. 2007, 56, 384-402. [CrossRef]

9. Ferreira-Vieira, T.; Guimaraes, I.; Silva, F.; Ribeiro, F. Alzheimer's disease: Targeting the cholinergic system. Curr. Neuropharmacol. 2016, 14, 101-115. [CrossRef]

10. Arvanitakis, Z.; Wilson, R.S.; Bienias, J.L.; Evans, D.A.; Bennett, D.A. Diabetes mellitus and risk of Alzheimer disease and decline in cognitive function. Arch. Neurol. 2004, 61, 661-666. [CrossRef]

11. Ristow, M. Neurodegenetive disorders associated with diabetes mellitus. J. Mol. Med. 2004, 82, 510-529. [CrossRef]

12. Haan, M.N. Therapy insight: Type 2 diabetes mellitus and the risk of late-onset Alzheimer's disease. Nat. Clin. Pr. Neurol. 2006, 2, 159-166. [CrossRef] [PubMed]

13. Kroner, Z. The relationship between Alzheimer's disease and diabetes: Type 3 diabetes? Altern. Med. Rev. 2009, 14, 373-379. [PubMed]

14. Qiu, W.Q.; Folstein, M.F. Insulin, insulin-degrading enzyme and amyloid- $\beta$ peptide in Alzheimer's disease: Review and hypothesis. Neurobiol. Aging 2006, 27, 190-198. [CrossRef]

15. Roberts, R.O.; Knopman, D.S.; Przybelski, S.A.; Mielke, M.M.; Kantarci, K.; Preboske, G.M.; Senjem, M.L.; Pankratz, V.S.; Geda, Y.E.; Boeve, B.F.; et al. Association of type 2 diabetes with brain atrophy and cognitive impairment. Neurology 2014, 82, 1132-1141. [CrossRef]

16. Rönnemaa, E.; Zethelius, B.; Sundelöf, J.; Sundström, J.; Degerman-Gunnarsson, M.; Berne, C.; Lannfelt, L.; Kilander, L. Impaired insulin secretion increases the risk of Alzheimer disease. Neurology 2008, 71, 1065-1071. [CrossRef]

17. Xu, W.L.; Von Strauss, E.; Qiu, C.X.; Winblad, B.; Fratiglioni, L. Uncontrolled diabetes increases the risk of Alzheimer's disease: A population-based cohort study. Diabetologia 2009, 52, 1031-1039. [CrossRef] [PubMed]

18. Mayeux, R.; Stern, Y. Epidemiology of Alzheimer disease. Cold Spring Harb. Perspect. Med. 2012, 2. [CrossRef]

19. Wang, K.-C.; Woung, L.-C.; Tsai, M.-T.; Liu, C.-C.; Su, Y.-H.; Li, C.-Y. Risk of Alzheimer's disease in relation to diabetes: A population-based cohort study. Neuroepidemiology 2012, 38, 237-244. [CrossRef]

20. Rowley, W.R.; Bezold, C.; Arikan, Y.; Byrne, E.; Krohe, S. Diabetes 2030: Insights from yesterday, today, and future trends. Popul. Health Manag. 2017, 20, 6-12. [CrossRef]

21. Maurer-Stroh, S.; Debulpaep, M.; Kuemmerer, N.; De La Paz, M.L.; Martins, I.C.; Reumers, J.; Morris, K.L.; Copland, A.; Serpell, L.; Serrano, L.; et al. Exploring the sequence determinants of amyloid structure using position-specific scoring matrices. Nat. Methods 2010, 7, 237-242. [CrossRef]

22. Hauser, C.A.E.; Maurer-Stroh, S.; Martins, I.C. Amyloid-based nanosensors and nanodevices. Chem. Soc. Rev. 2014, 43, 5326-5345. [CrossRef] [PubMed]

23. Raimundo, A.F.; Ferreira, S.; Martins, I.C.; Menezes, R. Islet amyloid polypeptide: A partner in crime with $\mathrm{A} \beta$ in the pathology of Alzheimer's disease. Front. Mol. Neurosci. 2020, 13, 35. [CrossRef] [PubMed]

24. Wineman-Fisher, V.; Bloch, D.N.; Miller, Y. Challenges in studying the structures of metal-amyloid oligomers related to type 2 diabetes, Parkinson's disease, and Alzheimer's disease. Coord. Chem. Rev. 2016, 327, 20-26. [CrossRef]

25. Yang, Y.; Wu, Y.; Zhang, S.; Song, W. High glucose promotes A $\beta$ production by inhibiting APP degradation. PLoS ONE 2013, 8. [CrossRef]

26. Zhang, Y.; Song, W. Islet amyloid polypeptide: Another key molecule in Alzheimer's pathogenesis? Prog. Neurobiol. 2017, 153, 100-120. [CrossRef]

27. Westermark, P.; Andersson, A.; Westermark, G.T. Islet amyloid polypeptide, islet amyloid, and diabetes mellitus. Physiol. Rev. 2011, 91, 795-826. [CrossRef]

28. Nishi, M.; Sanke, T.; Nagamatsu, S.; Bell, G.I.; Steiner, D.F. Islet amyloid polypeptide. A new $\beta$ cell secretory product related to islet amyloid deposits. J. Biol. Chem. 1990, 265, 4173-4176. 
29. Asthana, S.; Mallick, B.; Alexandrescu, A.T.; Jha, S. IAPP in type II diabetes: Basic research on structure, molecular interactions, and disease mechanisms suggests potential intervention strategies. Biochim. Biophys. Acta Biomembr. 2018, 1860, 1765-1782. [CrossRef]

30. Cao, P.; Marek, P.; Noor, H.; Patsalo, V.; Tu, L.H.; Wang, H.; Abedini, A.; Raleigh, D.P. Islet amyloid: From fundamental biophysics to mechanisms of cytotoxicity. FEBS Lett. 2013, 587, 1106-1118. [CrossRef]

31. Ahmad, E.; Ahmad, A.; Singh, S.; Arshad, M.; Khan, A.H.; Khan, R.H. A mechanistic approach for islet amyloid polypeptide aggregation to develop anti-amyloidogenic agents for type-2 diabetes. Biochimie 2011, 93, 793-805. [CrossRef]

32. Bailey, J.; Potter, K.J.; Verchere, C.B.; Edelstein-Keshet, L.; Coombs, D. Reverse engineering an amyloid aggregation pathway with dimensional analysis and scaling. Phys. Biol. 2011, 8, 66009. [CrossRef] [PubMed]

33. Janson, J.; Soeller, W.C.; Roche, P.C.; Nelson, R.T.; Torchia, A.J.; Kreutter, D.K.; Butler, P.C. Spontaneous diabetes mellitus in transgenic mice expressing human islet amyloid polypeptide. Proc. Natl. Acad. Sci. USA 1996, 93, 7283-7288. [CrossRef] [PubMed]

34. Janson, J.; Laedtke, T.; Parisi, J.E.; O’Brien, P.; Petersen, R.C.; Butler, P.C. Increased risk of type 2 diabetes in Alzheimer disease. Diabetes 2004, 53, 474-481. [CrossRef] [PubMed]

35. Ştefănescu, R.; Stanciu, G.D.; Luca, A.; Caba, I.C.; Tamba, B.I.; Mihai, C.T. Contributions of mass spectrometry to the identification of low molecular weight molecules able to reduce the toxicity of amyloid- $\beta$ peptide to cell cultures and transgenic mouse models of Alzheimer's disease. Molecules 2019, 24, 1167. [CrossRef]

36. Stanciu, G.D.; Luca, A.; Rusu, R.N.; Bild, V.; Chiriac, S.I.B.; Solcan, C.; Bild, W.; Ababei, D.C. Alzheimer's disease pharmacotherapy in relation to cholinergic system involvement. Biomolecules 2020, 10, 40. [CrossRef]

37. Selkoe, D.J. Soluble oligomers of the amyloid $\beta$-protein impair synaptic plasticity and behavior. Behav. Brain Res. 2008, 192, 106-113. [CrossRef]

38. Selkoe, D.J. Alzheimer's disease: Genes, proteins, and therapy. Physiol. Rev. 2001, 81, 741-766. [CrossRef]

39. Lambert, M.P.; Barlow, A.K.; Chromy, B.A.; Edwards, C.; Freed, R.; Liosatos, M.; Morgan, T.E.; Rozovsky, I.; Trommer, B.; Viola, K.L.; et al. Diffusible, nonfibrillar ligands derived from A $\beta 1-42$ are potent central nervous system neurotoxins. Proc. Natl. Acad. Sci. USA 1998, 95, 6448-6453. [CrossRef]

40. Hardy, J.; Selkoe, D.J. The amyloid hypothesis of Alzheimer's disease: Progress and problems on the road to therapeutics. Science 2002, 297, 353-356. [CrossRef]

41. Selkoe, D.J.; Hardy, J. The amyloid hypothesis of Alzheimer's disease at 25 years. EMBO Mol. Med. 2016, 8, 595-608. [CrossRef]

42. Morsy, A.; Trippier, P.C. Amyloid-binding alcohol dehydrogenase (ABAD) inhibitors for the treatment of Alzheimer's disease. J. Med. Chem. 2019, 62, 4252-4264. [CrossRef] [PubMed]

43. Tolar, M.; Abushakra, S.; Sabbagh, M. The path forward in Alzheimer's disease therapeutics: Reevaluating the amyloid cascade hypothesis. Alzheimer's Dement. 2020. [CrossRef] [PubMed]

44. Müller, U.C.; Deller, T.; Korte, M. Not just amyloid: Physiological functions of the amyloid precursor protein family. Nat. Rev. Neurosci. 2017, 18, 281-298. [CrossRef] [PubMed]

45. Mattson, M.P. Pathways towards and away from Alzheimer's disease. Nature 2004, 430, 631-639. [CrossRef] [PubMed]

46. Thinakaran, G.; Koo, E.H. Amyloid precursor protein trafficking, processing, and function. J. Biol. Chem. 2008, 283, 29615-29619. [CrossRef]

47. Li, Y.; Zhou, W.; Tong, Y.; He, G.; Song, W. Control of APP processing and A $\beta$ generation level by BACE1 enzymatic activity and transcription. FASEB J. 2006, 20, 285-292. [CrossRef]

48. Paroni, G.; Bisceglia, P.; Seripa, D. Understanding the amyloid hypothesis in Alzheimer's disease. J. Alzheimer's Dis. 2019, 68, 493-510. [CrossRef]

49. Hillen, H. The beta amyloid dysfunction (BAD) hypothesis for Alzheimer's disease. Front. Neurosci. 2019, 13, 1154. [CrossRef]

50. Manschot, S.M.; Brands, A.M.A.; Van Der Grond, J.; Kessels, R.P.C.; Algra, A.; Kappelle, L.J.; Biessels, G.J. Brain magnetic resonance imaging correlates of impaired cognition in patients with type 2 diabetes. Diabetes 2006, 55, 1106-1113. [CrossRef]

51. Pardeshi, R.; Bolshette, N.; Gadhave, K.; Ahire, A.; Ahmed, S.; Cassano, T.; Gupta, V.B.; Lahkar, M. Insulin signaling: An opportunistic target to minify risk of Alzheimer's disease. Psychoneuroendocrinology 2017, 83, 159-171. [CrossRef] 
52. Maloy, A.L.; Longnecker, D.S.; Greenberg, R.E. The relation of islet amyloid to the clinical type of diabetes. Hum. Pathol. 1981, 12, 917-922. [CrossRef]

53. Zhao, H.L.; Lai, F.M.M.; Tong, P.C.Y.; Zhong, D.R.; Yang, D.; Tomlinson, B.; Chan, J.C.N. Prevalence and clinicopathological characteristics of islet amyloid in chinese patients with type 2 diabetes. Diabetes 2003, 52, 2759-2766. [CrossRef] [PubMed]

54. Stanciu, G.D.; Musteaţă, M.; Armaşu, M.; Solcan, G. Evaluation of central vestibular syndrome in dogs using brainstem auditory evoked responses recorded with surface electrodes. Arq. Bras. Med. Vet. e Zootec. 2016, 68. [CrossRef]

55. Oskarsson, M.E.; Paulsson, J.F.; Schultz, S.W.; Ingelsson, M.; Westermark, P.; Westermark, G.T. In vivo seeding and cross-seeding of localized amyloidosis: A molecular link between type 2 diabetes and Alzheimer disease. Am. J. Pathol. 2015, 185, 834-846. [CrossRef] [PubMed]

56. Jackson, K.; Barisone, G.A.; Diaz, E.; Jin, L.W.; DeCarli, C.; Despa, F. Amylin deposition in the brain: A second amyloid in Alzheimer disease? Ann. Neurol. 2013, 74, 517-526. [CrossRef] [PubMed]

57. Cisternas, P.; Inestrosa, N.C. Brain glucose metabolism: Role of Wnt signaling in the metabolic impairment in Alzheimer's disease. Neurosci. Biobehav. Rev. 2017, 80, 316-328. [CrossRef]

58. Blázquez, E.; Velázquez, E.; Hurtado-Carneiro, V.; Ruiz-Albusac, J.M. Insulin in the brain: Its pathophysiological implications for states related with central insulin resistance, type 2 diabetes and alzheimer's disease. Front. Endocrinol. 2014, 5, 161. [CrossRef]

59. Bedse, G.; Di Domenico, F.; Serviddio, G.; Cassano, T. Aberrant insulin signaling in Alzheimer's disease: Current knowledge. Front. Neurosci. 2015, 9, 204. [CrossRef]

60. Talbot, K.; Wang, H.Y.; Kazi, H.; Han, L.Y.; Bakshi, K.P.; Stucky, A.; Fuino, R.L.; Kawaguchi, K.R.; Samoyedny, A.J.; Wilson, R.S.; et al. Demonstrated brain insulin resistance in Alzheimer's disease patients is associated with IGF-1 resistance, IRS-1 dysregulation, and cognitive decline. J. Clin. Investig. 2012, 122, 1316-1338. [CrossRef]

61. Aliev, G.; Priyadarshini, M.; Reddy, V.; Grieg, N.H.; Kaminsky, Y.; Cacabelos, R.; Ashraf, G.; Jabir, N.R.; Kamal, M.A.; Nikolenko, V.N.; et al. Oxidative stress mediated mitochondrial and vascular lesions as markers in the pathogenesis of Alzheimer disease. Curr. Med. Chem. 2014, 21, 2208-2217. [CrossRef]

62. Boccardi, V.; Murasecco, I.; Mecocci, P. Diabetes drugs in the fight against Alzheimer's disease. Ageing Res. Rev. 2019, 54, 100936. [CrossRef] [PubMed]

63. Delikkaya, B.; Moriel, N.; Tong, M.; Gallucci, G.; de la Monte, S.M. Altered expression of insulin-degrading enzyme and regulator of calcineurin in the rat intracerebral streptozotocin model and human apolipoprotein E-ع4-associated Alzheimer's disease. Alzheimer's Dement. Diagn. Assess. Dis. Monit. 2019, 11, $392-404$. [CrossRef] [PubMed]

64. Ashby, E.L.; Miners, J.S.; Kehoe, P.G.; Love, S. Effects of hypertension and anti-hypertensive treatment on amyloid- $\beta(\mathrm{A} \beta)$ plaque load and $\mathrm{A} \beta$-synthesizing and $\mathrm{A} \beta$-degrading enzymes in frontal cortex. J. Alzheimer's Dis. 2016, 50, 1191-1203. [CrossRef] [PubMed]

65. Saedi, E.; Gheini, M.R.; Faiz, F.; Arami, M.A. Diabetes mellitus and cognitive impairments. World J. Diabetes 2016, 7, 412. [CrossRef]

66. Kim, H.-G. Cognitive dysfunctions in individuals with diabetes mellitus. Yeungnam Univ. J. Med. 2019, 36, 183-191. [CrossRef]

67. Matsuzaki, T.; Sasaki, K.; Tanizaki, Y.; Hata, J.; Fujimi, K.; Matsui, Y.; Sekita, A.; Suzuki, S.O.; Kanba, S.; Kiyohara, Y.; et al. Insulin resistance is associated with the pathology of Alzheimer disease: The hisayama study. Neurology 2010, 75, 764-770. [CrossRef]

68. Le Roith, D.; Zick, Y. Recent advances in our understanding of insulin action and insulin resistance. Diabetes Care 2001, 24, 588-597. [CrossRef]

69. Zhao, W.Q.; Townsend, M. Insulin resistance and amyloidogenesis as common molecular foundation for type 2 diabetes and Alzheimer's disease. Biochim. Biophys. Acta Mol. Basis Dis. 2009, 1792, 482-496. [CrossRef]

70. Sankar, S.B.; Infante-Garcia, C.; Weinstock, L.D.; Ramos-Rodriguez, J.J.; Hierro-Bujalance, C.; Fernandez-Ponce, C.; Wood, L.B.; Garcia-Alloza, M. Amyloid beta and diabetic pathology cooperatively stimulate cytokine expression in an Alzheimer's mouse model. J. Neuroinflammation 2020, 17, 1-15. [CrossRef] 
71. Cukierman-Yaffe, T.; Gerstein, H.C.; Williamson, J.D.; Lazar, R.M.; Lovato, L.; Miller, M.E.; Coker, L.H.; Murray, A.; Sullivan, M.D.; Marcovina, S.M.; et al. Relationship between baseline glycemic control and cognitive function in individuals with type 2 diabetes and other cardiovascular rIsk factors the action to control cardiovascular risk in diabetes-memory in diabetes (ACCORD-MIND) trial. Diabetes Care 2009, 32, 221-226. [CrossRef]

72. Vlassara, H.; Bucala, R.; Striker, L. Pathogenic effects of advanced glycosylation: Biochemical, biologic, and clinical implications for diabetes and aging. Lab. Invest. 1994, 70, 138-151.

73. Serban, D.; Anton, E.; Chirita, R.; Bild, V.; Ciobica, A.; Alexinschi, O.; Arcan, O.; Popescu, R.; Paduraru, L.; Timofte, D. Current aspects of the interactions between dementia, the brain renin-angiotensin system and oxidative stress. Arch. Biol. Sci. 2015, 67, 903-907. [CrossRef]

74. Verdile, G.; Fuller, S.J.; Martins, R.N. The role of type 2 diabetes in neurodegeneration. Neurobiol. Dis. 2015, 84, 22-38. [CrossRef]

75. Vitek, M.P.; Bhattacharya, K.; Glendening, J.M.; Stopa, E.; Vlassara, H.; Bucala, R.; Manogue, K.; Cerami, A. Advanced glycation end products contribute to amyloidosis in Alzheimer disease. Proc. Natl. Acad. Sci. USA 1994, 91, 4766-4770. [CrossRef] [PubMed]

76. Iannuzzi, C.; Irace, G.; Sirangelo, I. Differential effects of glycation on protein aggregation and amyloid formation. Front. Mol. Biosci. 2014, 1, 9. [CrossRef] [PubMed]

77. Iannuzzi, C.; Irace, G.; Sirangelo, I. Role of glycation in amyloid: Effect on the aggregation process and cytotoxicity. In Exploring New Findings on Amyloidosis; InTech: London, UK, 2016.

78. Kapurniotu, A.; Bernhagen, J.; Greenfield, N.; Al-Abed, Y.; Teichberg, S.; Frank, R.W.; Voelter, W.; Bucala, R. Contribution of advanced glycosylation to the amyloidogenicity of islet amyloid polypeptide. Eur. J. Biochem. 1998, 251, 208-216. [CrossRef]

79. Chen, K.; Maley, J.; Yu, P.H. Potential implications of endogenous aldehydes in?-amyloid misfolding, oligomerization and fibrillogenesis. J. Neurochem. 2006, 99, 1413-1424. [CrossRef]

80. Iannuzzi, C.; Borriello, M.; Carafa, V.; Altucci, L.; Vitiello, M.; Balestrieri, M.L.; Ricci, G.; Irace, G.; Sirangelo, I. D-ribose-glycation of insulin prevents amyloid aggregation and produces cytotoxic adducts. Biochim. Biophys. Acta Mol. Basis Dis. 2016, 1862, 93-104. [CrossRef]

81. Sasaki, N.; Fukatsu, R.; Tsuzuki, K.; Hayashi, Y.; Yoshida, T.; Fujii, N.; Koike, T.; Wakayama, I.; Yanagihara, R.; Garruto, R.; et al. Advanced glycation end products in Alzheimer's disease and other neurodegenerative diseases. Am. J. Pathol. 1998, 153, 1149-1155. [CrossRef]

82. Ott, A.; Stolk, R.P.; Van Harskamp, F.; Pols, H.A.P.; Hofman, A.; Breteler, M.M.B. Diabetes mellitus and the risk of dementia: The Rotterdam study. Neurology 1999, 53, 1937-1942. [CrossRef]

83. Miklossy, J.; Qing, H.; Radenovic, A.; Kis, A.; Vileno, B.; Làszló, F.; Miller, L.; Martins, R.N.; Waeber, G.; Mooser, V.; et al. Beta amyloid and hyperphosphorylated tau deposits in the pancreas in type 2 diabetes. Neurobiol. Aging 2010, 31, 1503-1515. [CrossRef] [PubMed]

84. Akomolafe, A.; Beiser, A.; Meigs, J.B.; Au, R.; Green, R.C.; Farrer, L.A.; Wolf, P.A.; Seshadri, S. Diabetes mellitus and risk of developing Alzheimer disease: Results from the Framingham study. Arch. Neurol. 2006, 63, 1551-1555. [CrossRef] [PubMed]

85. Yamamoto, N.; Matsubara, T.; Sobue, K.; Tanida, M.; Kasahara, R.; Naruse, K.; Taniura, H.; Sato, T.; Suzuki, K. Brain insulin resistance accelerates A $\beta$ fibrillogenesis by inducing GM1 ganglioside clustering in the presynaptic membranes. J. Neurochem. 2012, 121, 619-628. [CrossRef] [PubMed]

86. Bourdel-Marchasson, I.; Lapre, E.; Laksir, H.; Puget, E. Insulin resistance, diabetes and cognitive function: Consequences for preventative strategies. Diabetes Metab. 2010, 36, 173-181. [CrossRef]

87. Reger, M.A.; Watson, G.S.; Green, P.S.; Wilkinson, C.W.; Baker, L.D.; Cholerton, B.; Fishel, M.A.; Plymate, S.R.; Breitner, J.C.S.; DeGroodt, W.; et al. Intranasal insulin improves cognition and modulates $\beta$-amyloid in early AD. Neurology 2008, 70, 440-448. [CrossRef] [PubMed]

88. Haj-ali, V.; Mohaddes, G.; Babri, S.H. Intracerebroventricular insulin improves spatial learning and memory in male Wistar rats. Behav. Neurosci. 2009, 123, 1309-1314. [CrossRef]

89. Kim, B.; Backus, C.; Oh, S.S.; Hayes, J.M.; Feldman, E.L. Increased tau phosphorylation and cleavage in mouse models of type 1 and type 2 diabetes. Endocrinology 2009, 150, 5294-5301. [CrossRef]

90. Ke, Y.D.; Delerue, F.; Gladbach, A.; Götz, J.; Ittner, L.M. Experimental diabetes mellitus exacerbates Tau pathology in a transgenic mouse model of Alzheimer's disease. PLoS ONE 2009, 4, e7917. [CrossRef] 
91. Mcclean, P.L.; Parthsarathy, V.; Faivre, E.; Holscher, C. The diabetes drug liraglutide prevents degenerative processes in a mouse model of Alzheimer's disease. J. Neurosci. 2011, 31, 6587-6594. [CrossRef]

92. Escribano, L.; Simón, A.M.; Gimeno, E.; Cuadrado-Tejedor, M.; De Maturana, R.L.; García-Osta, A.; Ricobaraza, A.; Pérez-Mediavilla, A.; Del Río, J.; Frechilla, D. Rosiglitazone rescues memory impairment in Alzheimer's transgenic mice: Mechanisms involving a reduced amyloid and tau pathology. Neuropsychopharmacology 2010, 35, 1593-1604. [CrossRef]

93. Peila, R.; Rodriguez, B.L.; Launer, L.J. Type 2 diabetes, APOE gene, and the risk for dementia and related pathologies: The Honolulu-Asia aging study. Diabetes 2002, 51, 1256-1262. [CrossRef] [PubMed]

94. Barbagallo, M. Type 2 diabetes mellitus and Alzheimer's disease. World J. Diabetes 2014, 5, 889. [CrossRef] [PubMed]

95. Baker, H.F.; Ridley, R.M.; Duchen, L.W.; Crow, T.J.; Bruton, C.J. Experimental induction of $\beta$-amyloid plaques and cerebral angiopathy in primates. Ann. NY Acad. Sci. 1993, 695, 228-231. [CrossRef] [PubMed]

96. Walker, L.C.; Callahan, M.J.; Bian, F.; Durham, R.A.; Roher, A.E.; Lipinski, W.J. Exogenous induction of cerebral $\beta$-amyloidosis in $\beta$ APP-transgenic mice. Peptides 2002, 23, 1241-1247. [CrossRef]

97. Eisele, Y.S.; Obermüller, U.; Heilbronner, G.; Baumann, F.; Kaeser, S.A.; Wolburg, H.; Walker, L.C.; Staufenbiel, M.; Heikenwalder, M.; Jucker, M. Peripherally applied A $\beta$-containing inoculates induce cerebral $\beta$-amyloidosis. Science 2010, 330, 980-982. [CrossRef]

98. Ridley, R.M.; Baker, H.F.; Windle, C.P.; Cummings, R.M. Very long term studies of the seeding of $\beta$-amyloidosis in primates. J. Neural Transm. 2006, 113, 1243-1251. [CrossRef]

99. Stöhr, J.; Watts, J.C.; Mensinger, Z.L.; Oehler, A.; Grillo, S.K.; De Armond, S.J.; Prusiner, S.B.; Giles, K. Purified and synthetic Alzheimer's amyloid beta (A $\beta$ ) prions. Proc. Natl. Acad. Sci. USA 2012, 109, 11025-11030. [CrossRef]

100. Pype, S.; Moechars, D.; Dillen, L.; Mercken, M. Characterization of amyloid $\beta$ peptides from brain extracts of transgenic mice overexpressing the London mutant of human amyloid precursor protein. J. Neurochem. 2003, 84, 602-609. [CrossRef]

101. Eisele, Y.S.; Fritschi, S.K.; Hamaguchi, T.; Obermüller, U.; Füger, P.; Skodras, A.; Schäfer, C.; Odenthal, J.; Heikenwalder, M.; Staufenbiel, M.; et al. Multiple factors contribute to the peripheral induction of cerebral $\beta$-amyloidosis. J. Neurosci. 2014, 34, 10264-10273. [CrossRef]

102. Sturchler-Pierrat, C.; Abramowski, D.; Duke, M.; Wiederhold, K.H.; Mistl, C.; Rothacher, S.; Ledermann, B.; Bürki, K.; Frey, P.; Paganetti, P.A.; et al. Two amyloid precursor protein transgenic mouse models with Alzheimer disease-like pathology. Proc. Natl. Acad. Sci. USA 1997, 94, 13287-13292. [CrossRef]

103. Lamb, B.T.; Call, L.M.; Slunt, H.H.; Bardel, K.A.; Lawler, A.M.; Eckman, C.B.; Younkin, S.G.; Holtz, G.; Wagner, S.L.; Price, D.L.; et al. Altered metabolism of familial Alzheimer's disease-linked amyloid precursor protein variants in yeast artificial chromosome transgenic mice. Hum. Mol. Genet. 1997, 6, 1535-1541. [CrossRef] [PubMed]

104. Takeda, S.; Sato, N.; Uchio-Yamada, K.; Sawada, K.; Kunieda, T.; Takeuchi, D.; Kurinami, H.; Shinohara, M.; Rakugi, H.; Morishita, R. Diabetes-accelerated memory dysfunction via cerebrovascular inflammation and A $\beta$ deposition in an Alzheimer mouse model with diabetes. Proc. Natl. Acad. Sci. USA 2010, 107, 7036-7041. [CrossRef] [PubMed]

105. Jiménez-Palomares, M.; Ramos-Rodríguez, J.J.; López-Acosta, J.F.; Pacheco-Herrero, M.; Lechuga-Sancho, A.M.; Perdomo, G.; García-Alloza, M.; Cózar-Castellano, I. Increased A $\beta$ production prompts the onset of glucose intolerance and insulin resistance. Am. J. Physiol. Metab. 2012, 302, E1373-E1380. [CrossRef] [PubMed]

106. Kitada, M.; Ogura, Y.; Koya, D. Rodent models of diabetic nephropathy: Their utility and limitations. Int. J. Nephrol. Renov. Dis. 2016, 9, 279-290. [CrossRef] [PubMed]

107. Glastras, S.J.; Chen, H.; Teh, R.; McGrath, R.T.; Chen, J.; Pollock, C.A.; Wong, M.G.; Saad, S. Mouse models of diabetes, obesity and related kidney disease. PLoS ONE 2016, 11, e0162131. [CrossRef]

108. Marzban, L.; Park, K.; Verchere, C.B. Islet amyloid polypeptide and type 2 diabetes. Exp. Gerontol. 2003, 38, 347-351. [CrossRef]

109. Tesch, G.H.; Allen, T.J. Rodent models of streptozotocin-induced diabetic nephropathy (methods in renal research). Nephrology 2007, 12, 261-266. [CrossRef]

110. Kalafatakis, K.; Zarros, A. Intracerebroventricular administration of streptozotocin as an experimental approach to Alzheimer's disease. Int. J. Neurosci. 2014, 124, 944-946. [CrossRef] 
111. Pruzin, J.J.; Nelson, P.T.; Abner, E.L.; Arvanitakis, Z. Review: Relationship of type 2 diabetes to human brain pathology. Neuropathol. Appl. Neurobiol. 2018, 44, 347-362. [CrossRef] [PubMed]

112. Chargé, S.B.P.; Esiri, M.M.; Bethune, C.A.; Hansen, B.C.; Clark, A. Apolipoprotein E is associated with islet amyloid and other amyloidoses: Implications for Alzheimer's disease. J. Pathol. 1996, 179, 443-447. [CrossRef]

113. Powell, D.S.; Maksoud, H.; Chargé, S.B.P.; Moffitt, J.H.; Desai, M.; Da Silva Fihlo, R.L.; Hattersley, A.T.; Stratton, I.M.; Matthews, D.R.; Levy, J.C.; et al. Apolipoprotein E genotype, islet amyloid deposition and severity of Type 2 diabetes. Diabetes Res. Clin. Pr. 2003, 60, 105-110. [CrossRef]

114. Wijesekara, N.; Ahrens, R.; Sabale, M.; Wu, L.; Ha, K.; Verdile, G.; Fraser, P.E. Amyloid-b and islet amyloid pathologies link Alzheimer's disease and type 2 diabetes in a transgenic model. FASEB J. 2017, 31, 5409-5418. [CrossRef] [PubMed]

115. Moreno-Gonzalez, I.; Edwards, G.; Salvadores, N.; Shahnawaz, M.; Diaz-Espinoza, R.; Soto, C. Molecular interaction between type 2 diabetes and Alzheimer's disease through cross-seeding of protein misfolding. Mol. Psychiatry 2017, 22, 1327-1334. [CrossRef] [PubMed]

116. Srodulski, S.; Sharma, S.; Bachstetter, A.B.; Brelsfoard, J.M.; Pascual, C.; Xie, X.S.; Saatman, K.E.; Van Eldik, L.J.; Despa, F. Neuroinflammation and neurologic deficits in diabetes linked to brain accumulation of amylin. Mol. Neurodegener. 2014, 9, 30. [CrossRef] [PubMed]

117. Okabayashi, S.; Shimozawa, N.; Yasutomi, Y.; Yanagisawa, K.; Kimura, N. Diabetes mellitus accelerates A $\beta$ pathology in brain accompanied by enhanced GA $\beta$ generation in nonhuman primates. PLoS ONE 2015, 10, e0117362. [CrossRef]

118. Infante-Garcia, C.; Ramos-Rodriguez, J.J.; Hierro-Bujalance, C.; Ortegon, E.; Pickett, E.; Jackson, R.; Hernandez-Pacho, F.; Spires-Jones, T.; Garcia-Alloza, M. Antidiabetic polypill improves central pathology and cognitive impairment in a mixed model of Alzheimer's disease and type 2 diabetes. Mol. Neurobiol. 2018, 55, 6130-6144. [CrossRef]

119. Ou, Z.; Kong, X.; Sun, X.; He, X.; Zhang, L.; Gong, Z.; Huang, J.; Xu, B.; Long, D.; Li, J.; et al. Metformin treatment prevents amyloid plaque deposition and memory impairment in APP/PS1 mice. Brain. Behav. Immun. 2018, 69, 351-363. [CrossRef]

120. Bomfim, T.R.; Forny-Germano, L.; Sathler, L.B.; Brito-Moreira, J.; Houzel, J.C.; Decker, H.; Silverman, M.A.; Kazi, H.; Melo, H.M.; McClean, P.L.; et al. An anti-diabetes agent protects the mouse brain from defective insulin signaling caused by Alzheimer's disease-associated A $\beta$ oligomers. J. Clin. Investig. 2012, 122, 1339-1353. [CrossRef]

121. Batista, A.F.; Forny-Germano, L.; Clarke, J.R.; Lyra-Silva, N.M.; Brito-Moreira, J.; Boehnke, S.E.; Winterborn, A.; Coe, B.C.; Lablans, A.; Vital, J.F.; et al. The diabetes drug liraglutide reverses cognitive impairment in mice and attenuates insulin receptor and synaptic pathology in a non-human primate model of Alzheimer's disease. J. Pathol. 2018, 245, 85-100. [CrossRef]

122. Fernandez-Martos, C.M.; Atkinson, R.A.K.; Chuah, M.I.; King, A.E.; Vickers, J.C. Combination treatment with leptin and pioglitazone in a mouse model of Alzheimer's disease. Alzheimer's Dement. Transl. Res. Clin. Interv. 2017, 3, 92-106. [CrossRef]

123. Ma, D.L.; Chen, F.Q.; Xu, W.J.; Yue, W.Z.; Yuan, G.; Yang, Y. Early intervention with glucagon-like peptide 1 analog liraglutide prevents tau hyperphosphorylation in diabetic db/db mice. J. Neurochem. 2015, 135, 301-308. [CrossRef] [PubMed]

124. Kickstein, E.; Krauss, S.; Thornhill, P.; Rutschow, D.; Zeller, R.; Sharkey, J.; Williamson, R.; Fuchs, M.; Köhler, A.; Glossmann, H.; et al. Biguanide metformin acts on tau phosphorylation via mTOR/protein phosphatase 2A (PP2A) signaling. Proc. Natl. Acad. Sci. USA 2010, 107, 21830-21835. [CrossRef] [PubMed]

125. Heneka, M.T.; Sastre, M.; Dumitrescu-Ozimek, L.; Hanke, A.; Dewachter, I.; Kuiperi, C.; O’Banion, K.; Klockgether, T.; Van Leuven, F.; Landreth, G.E. Acute treatment with the PPARgamma agonist pioglitazone and ibuprofen reduces glial inflammation and Abeta1-42 levels in APPV717I transgenic mice. Brain 2005, 128, 1442-1453. [CrossRef]

126. Hölscher, C. The incretin hormones glucagonlike peptide 1 and glucose-dependent insulinotropic polypeptide are neuroprotective in mouse models of Alzheimer's disease. Alzheimer's Dement. 2014, 10, S47-S54.

127. Wang, J.; Gallagher, D.; Devito, L.M.; Cancino, G.I.; Tsui, D.; He, L.; Keller, G.M.; Frankland, P.W.; Kaplan, D.R.; Miller, F.D. Metformin activates an atypical PKC-CBP pathway to promote neurogenesis and enhance spatial memory formation. Cell Stem Cell 2012, 11, 23-35. [CrossRef] 
128. Pathak, N.M.; Pathak, V.; Gault, V.A.; McClean, S.; Irwin, N.; Flatt, P.R. Novel dual incretin agonist peptide with antidiabetic and neuroprotective potential. Biochem. Pharm. 2018, 155, 264-274. [CrossRef]

129. McClean, P.L.; Hölscher, C. Lixisenatide, a drug developed to treat type 2 diabetes, shows neuroprotective effects in a mouse model of Alzheimer's disease. Neuropharmacology 2014, 86, 241-258. [CrossRef]

130. Gupta, A.; Bisht, B.; Dey, C.S. Peripheral insulin-sensitizer drug metformin ameliorates neuronal insulin resistance and Alzheimer's-like changes. Neuropharmacology 2011, 60, 910-920. [CrossRef]

131. DiTacchio, K.A.; Heinemann, S.F.; Dziewczapolski, G. Metformin treatment alters memory function in a mouse model of Alzheimer's disease. J. Alzheimer's Dis. 2015, 44, 43-48. [CrossRef]

132. Ng, T.P.; Feng, L.; Yap, K.B.; Lee, T.S.; Tan, C.H.; Winblad, B. Long-term metformin usage and cognitive function among older adults with diabetes. J. Alzheimer's Dis. 2014, 41, 61-68. [CrossRef]

133. Imfeld, P.; Bodmer, M.; Jick, S.S.; Meier, C.R. Metformin, other antidiabetic drugs, and risk of Alzheimer's disease: A population-based case-control study. J. Am. Geriatr. Soc. 2012, 60, 916-921. [CrossRef] [PubMed]

134. Esmaeili, M.H.; Bahari, B.; Salari, A.A. ATP-sensitive potassium-channel inhibitor glibenclamide attenuates HPA axis hyperactivity, depression-and anxiety-related symptoms in a rat model of Alzheimer's disease. Brain Res. Bull. 2018, 137, 265-276. [CrossRef] [PubMed]

135. Cao, B.; Rosenblat, J.D.; Brietzke, E.; Park, C.; Lee, Y.; Musial, N.; Pan, Z.; Mansur, R.B.; McIntyre, R.S. Comparative efficacy and acceptability of antidiabetic agents for Alzheimer's disease and mild cognitive impairment: A systematic review and network meta-analysis. Diabetes Obes. Metab. 2018, 20, 2467-2471. [CrossRef] [PubMed]

136. Armaşu, M.; Musteaţă, M.; Stanciu, G.D.; Mocanu, D.; Solcan, G. Brainstem auditory evoked responses in healthy Argentine Mastiffdogs recorded with surface electrodes. Arq. Bras. Med. Vet. e Zootec. 2015, 67. [CrossRef]

137. Geldmacher, D.S.; Fritsch, T.; McClendon, M.J.; Landreth, G. A randomized pilot clinical trial of the safety of pioglitazone in treatment of patients with Alzheimer disease. Arch. Neurol. 2011, 68, 45-50. [CrossRef]

138. Watson, G.S.; Cholerton, B.A.; Reger, M.A.; Baker, L.D.; Plymate, S.R.; Asthana, S.; Fishel, M.A.; Kulstad, J.J.; Green, P.S.; Cook, D.G.; et al. Preserved cognition in patients with early Alzheimer disease and amnestic mild cognitive impairment during treatment with rosiglitazone: A preliminary study. Am. J. Geriatr. Psychiatry 2005, 13, 950-958. [CrossRef]

139. Risner, M.E.; Saunders, A.M.; Altman, J.F.B.; Ormandy, G.C.; Craft, S.; Foley, I.M.; Zvartau-Hind, M.E.; Hosford, D.A.; Roses, A.D. Efficacy of rosiglitazone in a genetically defined population with mild-to-moderate Alzheimer's disease. Pharm. J. 2006, 6, 246-254. [CrossRef]

140. Harrington, C.; Sawchak, S.; Chiang, C.; Davies, J.; Donovan, C.M.; Saunders, A.; Irizarry, M.; Jeter, B.; Zvartau-Hind, M.H.; van Dyck, C.; et al. Rosiglitazone does not improve cognition or global function when used as adjunctive therapy to AChE inhibitors in mild-to-moderate Alzheimers disease: Two phase 3 studies. Curr. Alzheimer Res. 2011, 8, 592-606. [CrossRef]

141. Cai, H.Y.; Wang, Z.J.; Hölscher, C.; Yuan, L.; Zhang, J.; Sun, P.; Li, J.; Yang, W.; Wu, M.N.; Qi, J.S. Lixisenatide attenuates the detrimental effects of amyloid $\beta$ protein on spatial working memory and hippocampal neurons in rats. Behav. Brain Res. 2017, 318, 28-35. [CrossRef]

142. Stanciu, G.-D.; Packer, R.M.A.; Pakozdy, A.; Solcan, G.; Volk, H.A. Clinical reasoning in feline epilepsy: Which combination of clinical information is useful? Vet. J. 2017, 225, 9-12. [CrossRef]

143. Zhou, M.; Chen, S.; Peng, P.; Gu, Z.; Yu, J.; Zhao, G.; Deng, Y. Dulaglutide ameliorates STZ induced AD-like impairment of learning and memory ability by modulating hyperphosphorylation of tau and NFs through GSK3ß. Biochem. Biophys. Res. Commun. 2019, 511, 154-160. [CrossRef] [PubMed]

144. Qi, L.Q.; Chen, Z.; Wang, Y.P.; Liu, X.Y.; Liu, X.H.; Ke, L.F.; Zheng, Z.; Lin, X.W.; Zhou, Y.; Wu, L.J.; et al. Subcutaneous liraglutide ameliorates methylglyoxal-induced alzheimer-like tau pathology and cognitive impairment by modulating tau hyperphosphorylation and glycogen synthase kinase-3ß. Am. J. Transl. Res. 2017, 9, 247-260. [PubMed]

145. Han, W.N.; Hölscher, C.; Yuan, L.; Yang, W.; Wang, X.H.; Wu, M.N.; Qi, J.S. Liraglutide protects against amyloid- $\beta$ protein-induced impairment of spatial learning and memory in rats. Neurobiol. Aging 2013, 34, 576-588. [CrossRef] 
146. Duarte, A.I.; Candeias, E.; Alves, I.N.; Mena, D.; Silva, D.F.; Machado, N.J.; Campos, E.J.; Santos, M.S.; Oliveira, C.R.; Moreira, P.I. Liraglutide protects against brain amyloid- $\beta 1-42$ accumulation in female mice with early Alzheimer's disease-like pathology by partially rescuing oxidative/nitrosative stress and inflammation. Int. J. Mol. Sci. 2020, 21, 1746. [CrossRef] [PubMed]

147. Gejl, M.; Gjedde, A.; Egefjord, L.; Møller, A.; Hansen, S.B.; Vang, K.; Rodell, A.; Brændgaard, H.; Gottrup, H.; Schacht, A.; et al. In Alzheimer's disease, 6-month treatment with GLP-1 analog prevents decline of brain glucose metabolism: Randomized, placebo-controlled, double-blind clinical trial. Front. Aging Neurosci. 2016, 8, 108. [CrossRef]

148. Kosaraju, J.; Gali, C.C.; Khatwal, R.B.; Dubala, A.; Chinni, S.; Holsinger, R.M.D.; Madhunapantula, V.S.R.; Nataraj, S.K.M.; Basavan, D. Saxagliptin: A dipeptidyl peptidase-4 inhibitor ameliorates streptozotocin induced Alzheimer's disease. Neuropharmacology 2013, 72, 291-300. [CrossRef]

149. Kosaraju, J.; Murthy, V.; Khatwal, R.B.; Dubala, A.; Chinni, S.; Muthureddy Nataraj, S.K.; Basavan, D. Vildagliptin: An anti-diabetes agent ameliorates cognitive deficits and pathology observed in streptozotocin-induced Alzheimer's disease. J. Pharm. Pharm. 2013, 65, 1773-1784. [CrossRef]

150. Ma, Q.H.; Jiang, L.F.; Mao, J.L.; Xu, W.X.; Huang, M. Vildagliptin prevents cognitive deficits and neuronal apoptosis in a rat model of Alzheimer's disease. Mol. Med. Rep. 2018, 17, 4113-4119. [CrossRef]

151. Zhang, D.D.; Shi, N.; Fang, H.; Ma, L.; Wu, W.P.; Zhang, Y.Z.; Tian, J.L.; Tian, L.B.; Kang, K.; Chen, S. Vildagliptin, a DPP4 inhibitor, alleviates diabetes-associated cognitive deficits by decreasing the levels of apoptosis-related proteins in the rat hippocampus. Exp. Med. 2018, 15, 5100-5106. [CrossRef]

152. Dong, Q.; Teng, S.W.; Wang, Y.; Qin, F.; Li, Y.; Ai, L.L.; Yu, H. Sitagliptin protects the cognition function of the Alzheimer's disease mice through activating glucagon-like peptide-1 and BDNF-TrkB signalings. Neurosci. Lett. 2019, 696, 184-190. [CrossRef]

153. Bild, V.; Ababei, D.C.; Neamtu, M.; Vasincu, A.; Bild, W.; Stanciu, G.D.; Tamba, B.I.; Solcan, G.; Beschea Chiriac, S. Isobolar analysis of the binary fixed-ratio combination of acetylsalicilic acid-acetaminophen. Farmacia 2017, 65, 563-566.

154. Kosaraju, J.; Holsinger, R.M.D.; Guo, L.; Tam, K.Y. Linagliptin, a dipeptidyl peptidase-4 inhibitor, mitigates cognitive deficits and pathology in the 3xTg-AD mouse model of Alzheimer's disease. Mol. Neurobiol. 2017, 54, 6074-6084. [CrossRef] [PubMed]

155. Kornelius, E.; Lin, C.L.; Chang, H.H.; Li, H.H.; Huang, W.N.; Yang, Y.S.; Lu, Y.L.; Peng, C.H.; Huang, C.N. DPP-4 inhibitor linagliptin attenuates A $\beta$-induced cytotoxicity through activation of AMPK in neuronal cells. CNS Neurosci. 2015, 21, 549-557. [CrossRef] [PubMed]

156. Adler, B.L.; Yarchoan, M.; Hwang, H.M.; Louneva, N.; Blair, J.A.; Palm, R.; Smith, M.A.; Lee, H.G.; Arnold, S.E.; Casadesus, G. Neuroprotective effects of the amylin analogue pramlintide on Alzheimer's disease pathogenesis and cognition. Neurobiol. Aging 2014, 35, 793-801. [CrossRef] [PubMed]

157. Arafa, N.M.S.; Ali, E.H.A.; Hassan, M.K. Canagliflozin prevents scopolamine-induced memory impairment in rats: Comparison with galantamine hydrobromide action. Chem. Biol. Interact. 2017, 277, 195-203. [CrossRef] [PubMed]

158. Shingo, A.S.; Kanabayashi, T.; Kito, S.; Murase, T. Intracerebroventricular administration of an insulin analogue recovers STZ-induced cognitive decline in rats. Behav. Brain Res. 2013, 241, 105-111. [CrossRef]

159. Reger, M.A.; Watson, G.S.; Frey, W.H.; Baker, L.D.; Cholerton, B.; Keeling, M.L.; Belongia, D.A.; Fishel, M.A.; Plymate, S.R.; Schellenberg, G.D.; et al. Effects of intranasal insulin on cognition in memory-impaired older adults: Modulation by APOE genotype. Neurobiol. Aging 2006, 27, 451-458. [CrossRef]

160. Stanciu, G.D.; Solcan, G. Acute idiopathic polyradiculoneuritis concurrent with acquired myasthenia gravis in a West Highland white terrier dog. BMC Vet. Res. 2016, 12, 111. [CrossRef]

161. Claxton, A.; Baker, L.D.; Hanson, A.; Trittschuh, E.H.; Cholerton, B.; Morgan, A.; Callaghan, M.; Arbuckle, M.; Behl, C.; Craft, S. Long-acting intranasal insulin detemir improves cognition for adults with mild cognitive impairment or early-stage Alzheimer's disease dementia. J. Alzheimer's Dis. 2015, 44, 897-906. [CrossRef]

162. Goyal, D.; Shuaib, S.; Mann, S.; Goyal, B. Rationally designed peptides and peptidomimetics as inhibitors of amyloid- $\beta(\mathrm{A} \beta)$ aggregation: Potential therapeutics of Alzheimer's disease. ACS Comb. Sci. 2017, 19, 55-80. [CrossRef]

163. Dougherty, P.G.; Qian, Z.; Pei, D. Macrocycles as protein-protein interaction inhibitors. Biochem. J. 2017, 474, 1109-1125. [CrossRef] [PubMed] 
164. Yan, L.-M.; Velkova, A.; Tatarek-Nossol, M.; Rammes, G.; Sibaev, A.; Andreetto, E.; Kracklauer, M.; Bakou, M.; Malideli, E.; Göke, B.; et al. Selectively N-methylated soluble IAPP mimics as potent IAPP receptor agonists and nanomolar inhibitors of cytotoxic self-assembly of both IAPP and A $\beta 40$. Angew. Chem. Int. Ed. 2013, 52, 10378-10383. [CrossRef] [PubMed]

165. O'Nuallain, B.; Williams, A.D.; Westermark, P.; Wetzel, R. Seeding specificity in amyloid growth induced by heterologous fibrils. J. Biol. Chem. 2004, 279, 17490-17499. [CrossRef] [PubMed]

166. Spanopoulou, A.; Heidrich, L.; Chen, H.R.; Frost, C.; Hrle, D.; Malideli, E.; Hille, K.; Grammatikopoulos, A.; Bernhagen, J.; Zacharias, M.; et al. Designed macrocyclic peptides as nanomolar amyloid inhibitors based on minimal recognition elements. Angew. Chem. Int. Ed. 2018, 57, 14503-14508. [CrossRef] [PubMed]

(C) 2020 by the authors. Licensee MDPI, Basel, Switzerland. This article is an open access article distributed under the terms and conditions of the Creative Commons Attribution (CC BY) license (http://creativecommons.org/licenses/by/4.0/). 